\title{
Osmanlı Arşivinde Mersin Tarihine İlişkin Kaynaklar ${ }^{1}$
}

\author{
Songül ULUTAŞ \\ Dr. Öğr. Üyesi, Mersin Üniversitesi, \\ Fen Edebiyat Fakültesi, Tarih Bölümü \\ snglulutas@gmail.com \\ Orcid ID: https://orcid.org/0000-0002-7605-9151
}

Öz

Bu çalışmanın amacı, Mersin Tarihine ilişkin Osmanlı Dönemi kaynaklarının tespit edilip değerlendirilmesidir. $\mathrm{Bu}$ amaçla Cumhurbaşkanlığ 1 Osmanlı Arşivi'nde tasnif edilmiş ve elektronik kayda geçirilmiş tüm belgeler taranmış ve Mersin ile ilgili olanları tespit edilmiştir. Osmanlı Arşivindeki resmi devlet kayıtlarını içeren belgeler, devletin idari teşkilatının, ekonomik, sosyal ve kültürel yapısının, kurumların işleyiş̧inin ve kurumlar arasındaki hiyerarşik düzenin aydınlatılması bakımından büyük önem taşımaktadır. Bu genel yapı içerisinde taşra teşkilatlanması ve yerel idari birimler olarak kentlerle de ilgili oldukça zengin veriler mevcuttur. Çalışmanın bir diğer amacı bir kent tarihi çalışmasında kullanılabilecek temel birincil kaynakların ortaya konulmasıdır. Böylece Mersin Kent Tarihi çalışmak isteyen bir araştırmacının Osmanlı Dönemi için hangi birincil kaynaklara bakması gerektiği üzerine yönlendirici bir etki yaratılmak istenmektedir. Mersin Tarihine ilişkin böyle bir çalışmanın olmayışı nedeniyle bu çalışma alana katkı sunacaktır. Çalışmamızda öncelikle Mersin Tarihine ilişkin Osmanlı kaynakları hakkında bilgiler verildikten sonra bu kaynakların ne tür veriler içerdiği anlatılmaktadır.

Anahtar Kelimeler: Osmanlı Kaynakları, Kent Tarihi, Mersin.

\section{The Sources On The History Of Mersin In The Ottoman Archive}

\begin{abstract}
The aim of this study is to determine and evaluate the Ottoman period sources regarding history of Mersin. For this purpose, all documents classified in the Presidential Ottoman Archive and electronically recorded were scanned and those related to Mersin were identified. Documents containing official state

${ }^{1}$ Makale Geliş/Kabul Tarihi: 02.10.2019 / 01.04.2020

Künye Bilgisi: Ulutaş, S. (2020). Osmanlı Arşivinde Mersin Tarihine İlişkin Kaynaklar. Kahramanmaraş Sütçü İmam Üniversitesi Sosyal Bilimler Dergisi, 17 (1), 487-518. DOI: 10.33437/ksusbd.628539
\end{abstract}


records in the Ottoman Archive have a great importance for the clarification of the administrative organization of the state, its economic, social and cultural structure, the functioning of the institutions and the hierarchical order between the institutions. Within this general structure, there are very rich data about provincial organizations and cities as local administrative units. Another aim of the study is to reveal the main primary sources that can be used in a city history study. Thus, it is desired to create a guiding effect on which primary sources a researcher who wants to study Mersin urban history should look for during the Ottoman period. Due to the absence of such a study on the History of Mersin, this study will contribute to the field. In our study, first of all, information about Ottoman sources about Mersin history is given and told what kind of data these sources contain.

Keywords: Ottoman Resources, Urban History, Mersin.

\section{Giriş}

Antik çağlardan günümüze kadar şehir ya da kent dediğimiz yapı sürekli bir değişim ve dönüşüm içerisinde olmuştur. Kentler insanlık tarihi boyunca uygarlı̆̆ın doğduğu, büyüdüğü şekil aldığı ve bugünlere geldiği bir alandır. Son dönemlerde tarihçilikte ortaya konulan yeni yaklaşımlar çerçevesinde zamanla birlikte mekânların da önemine dikkat çekilmesi kentlerin uygarlık tarihinde oynadıkları rolün daha fazla irdelenmesini sağlamıştır (Braudel 2001). Bu yaklaşım aynı zamanda araştırıcıları yerelin tarihine ve rolüne daha fazla yönlendirmiştir.

Türkiye'de kent tarihiyle ilgili çalışmalar son y1llarda giderek artmaktadır. ${ }^{2}$ Kent tarihi, yeni bir toplumsal tarih yazımı alanı olarak gelişmekte ve kent tarihçileri özneleri olan kentleri farklı açılardan ele almaktadırlar. Kent tarihi

\footnotetext{
${ }^{2}$ Mersin Tarihi çalışmaları da son zamanlarda ilgi görmekte ve yapılan çalışmalar artmaktadır. Bu noktada Mersin kent tarihi ile ilgili yapılmış çalışmalara birkaç örnek olarak şu kaynaklar verilebilir: İbrahim Halil Aytar, Mersin Limanı, Mersin Ticaret Odası Yayınları, İstanbul 2016. İbrahim Emine Dingeç, 19. Yüzyllın Yarısında ve 20. Yüzyllın Başında Mersin'de Ekonomik Yapı, Yayınlanmamış Yüksek Lisans Tezi, Eskişehir, 1998. Tülin Selvi Ünlü, 19. Yüzyılda Mersin'in Kentsel Gelişimi, Yayımlanmamış Yüksek Lisans Tezi, Mersin, 2007. Rüştü Çelik, 1898 Kandiye Olayları Sonrasında Girit'ten Mersin Sancağına Göçler (1898-1907), Yayımlanmamış Yüksek Lisans Tezi, Mersin, 2009. Mehmet Doğan, Türkiye Cumhuriyetinin Eğitim Politikası ve Mersinde Eğitim (1923-1950), Yayımlanmamış Yüksek Lisans Tezi, Mersin, 2005. İbrahim Oğuz, Tarsus Şer'iyye Sicillerine Göre Mersin Kentinin Kuruluş Öyküsü, Yayımlanmamış Yüksek Lisans Tezi, Mersin, 2006.
} 
yazımı üzerine farklı yaklaşımlar öneren İlhan Tekeli'ye göre, Osmanlı düzenini daha iyi kavramak amaciyla yerel tarih ve kent monografileri oluşturan araştırmacılar eserlerinde genellikle tapu tahrir, evkâf, mühimme, ruus, maliye, şer'iyye sicil defterleri gibi arşiv kaynaklarına dayanarak Osmanlı düzeni ve sosyo-ekonomik yapı analizleri yapmaktadır (Tekeli, 1998: 149). 1990’lardan itibaren yoğunlaşan bu tür çalışmalarda, Osmanlı düzeninin İmparatorluğun değişik yörelerine nasıl uygulandığını ortaya çıkarmak amaçlanmaktadır (ÖzelÇetinsaya, 2002: 22-23).

Anadolu'daki yerleşim tarihine baktığımızda yaklaşık 10.000 yıllık bir geçmişe sahip olduğu görülmektedir. Mersin'i de içine alan antik adıyla Kilikia bugünkü adıyla Çukurova Bölgesi ise Anadolu'nun en eski yerleşim bölgelerinden biridir. Antik dönemde Adana, Tarsus ve Mersin bölgenin en işlek güzergâhı idi. Her ne kadar Osmanlı Dönemi'nde Mersin bölgede kuruluşunu en geç tamamlayan genç kentlerden biri olsa da antik dönemde Mersin'den Tarsus'a Kilikia kıyılarında Zephyrion, Ingira, Aulai, Ankhiale, Kyinda, Kundi, Sizzu gibi kayıp kentlerin olduğuna dair bulgular tespit edilmiştir (Durukan, 2015). Mersin tarih boyunca Hititler, Asurlar, Medler, Persler, Büyük İskender'in kurduğu Makedon İmparatorluğu, Roma İmparatorluğu, Bizans, Ermeni Krallı̆̆ Abbasiler, Selçuklular ve Osmanlılar gibi birçok devletin kontrolüne girmiştir. Mersin'in Osmanlı idaresine girmesi ise II. Mehmet zamanında gerçekleştirildi. $\mathrm{Bu}$ zamana kadar Mersin ve çevresi Karamanoğullarının kontrolündeydi. Mersin'de Osmanlı hakimiyeti 1483'te II. Bayezid döneminde kesin olarak sağlandı. Mersin Sancağ 1500 ve 1518 yıllarında Ermenek, Gülnar, Karataş ve Mut olmak üzere dört kazadan oluşmaktaydı. 1522'de Selendi, 1555 'te Silifke, 1584 'te Anamur, Bozdoğan, Sinanlı kazalarının kurulmasıyla birlikte kaza sayısı dokuza yükseldi (Çelik, 2000: 450-455). 19. Yüzyılda yaşanan kapitalist üretim ilişkilerindeki gelişmelerin Osmanlı coğrafyasına yansıması sonucu Mersin bir liman kent olarak büyümüş ve kentsel dokusu oluşmuştur (Ünlü, 2007: 74). Mersin yerleşiminin idari bir birim olarak ne zaman ortaya çıktığı ile ilgili net bir bilgi maalesef bulunmamaktadır. Evliya Çelebi 17. Yüzyılda ünlü seyahatnamesinde Kariye-i Mersin O $\breve{g} l u$ olarak ifade ettiği Mersin'i 70 haneli bir Türkmen köyü olarak tanımlamıştır (Çelebi, 1935: 327). Mersin'in 1840'lı yıllara kadar birkaç barakanın ve dükkânın bulunduğu balıķı köyü olduğu bilinmektedir. Kaynaklarda ise uzunca bir süre Mersin bir idari birim olarak değil de Mersin İskelesi olarak geçmektedir. 1840'ların başından itibaren Mersin köy olarak zikredilmeye başlanmıştır. Mersin Tarsus'un Gökçeli Kazası'na bağlı bir balıkçı köyü olarak idari birim statüsünü almıştır. Hızla büyüyen Mersin 1864 sonrasında Halep Vilâyeti'ne bağlı Adana Sancağı'nın Gökçeli, Kalınlı ve Elvanlı Nahiyelerinden oluşan bir kazası statüsünü almıştır. 1877'de Adana Vilâyeti'ne bağlı kaza merkezi konumuna yükseldi. 1888'de yine Adana Vilâyeti'ne bağli sancak merkezi oldu. Cumhuriyet dönemine kadar bu konumunu koruyan Mersin Sancağı artık bir vilayet oldu (Oğuz, 2005: 19-21). 
1933 yılında İçel ile Mersin birleştirilerek İçel (Mersin) Vilâyeti olmuştur. 2002'de ise Mersin mi İçel mi tartışmalarına son verilerek Mersin adı hem il adı hem de il merkezi olarak kullanılmaya başlanmıştır (Bozkurt, 2018: 29, 32-41). Çalışmamıza konu olan sınır Mersin merkez olarak belirlenmiştir.

Osmanlı Dönemi kent tarihi araştırmalarında birinci elden kaynak olan Osmanlı arşiv belgeleri kentlerin idari, ekonomik ve sosyal yönden gelişimini göstermesi açısından önemlidir. Osmanlı Devleti'nin idari teşkilatında ve ekonomik yapısında meydana gelen değişimlerin etkisi kent tarihi kaynaklarında da kendisini göstermiştir.

Osmanlı dönemi kent tarihi çalışmaları için Cumhurbaşkanlığı Osmanlı Arşivi'nde yapılan araştırmalarımızda çok sayıda arşiv belgesine ulaşmak mümkündür. Arşivde farklı fonlarda perakende ve defter şeklinde bulunan bu tasnifler içerisinde Osmanlı Dönemi Mersin Tarihi üzerine 6925 adet kayıt bulunmaktadır. Ancak Osmanlı Arşivi'nde tasnif edilmemiş çok sayıda belge bulunduğunu ve tasnif çalışmalarının devam ettiğini göz önünde bulundurarak tarama yapılan tarihte tespit edilen belgelerden çok daha fazla belge bulunabileceğini de belirtmek gerekmektedir. Ayrıca belirtilmesi gereken bir diğer husus yapılan taramalar arşivin elektronik tarama sistemi aracılığı ile yapılmıştır. Bu nedenle anahtar sözcüğümüz "Mersin" kelimesidir. Elde edilen sonuçlar belge özetlerinde Mersin anahtar sözcüğü geçen belgeleri içermektedir. Tespit edilen bu sonuçların dışında bazı belgelerin içinde Mersin'le ilgili bilgilerin yer alabileceği gerçeği de kabul edilmekte ve ayrı tutulmaktadır.

Araştırma sonucunda Osmanlı Arşivi'nde yapılan tarama sonucunda tespit edilen belgelerin bulunduğu fon kodları aşağıda belirtildiği şekildedir:

- Ali Emirî Tasnifi Belgeleri

- Bâb-1 Âlî Evrâk Odası Belgeleri

- Dâhiliye Nezâreti Belgeleri

- Dîvân-1 Hümâyûn ve Bâb-1 Asâfî Belgeleri

- Evkâf Defterleri

- Fotoğraflar, Plan, Proje ve Krokiler

- Hâriciye Nezâreti Belgeleri

- Haritalar

- Hatt-1 Hümâyûn Tasnifleri 
- Hazîne-i Hâssa İrâdeleri

- İrâdeler

- Mâliyeden Müdevver Defterler

- Maârif Nezâreti Belgeleri

- Mâliye Nezâreti belgeleri

- Meclis-i Vâlâ Evrâkları

- Meclis-i Vükelâ Mazbataları

- Muallim Cevdet Tasnifi Belgeleri

- Mühimme Defterleri

- Sadâret Defterleri ve Sadâret Mektûbî Belgeleri

- Sâlnâmeler

- Şer'iyye Sicilleri

- Şûrâ-yı Devlet Belgeleri

- Ticâret, Nâfia, Orman, Maâdin ve Zirâat Nezâretlerine Ait Defterler

- Topkapı Sarayı-Müze Arşivi Evrâkları

- Yıldız Sarayı Arşivi Belgeleri

- Zabtiye Nezâreti Belgeleri

Yukarıdaki tasniflerde bulunan belgelerde Osmanlı Dönemi Mersin'i hakkında siyasi, iktisadi, idari, sosyal, kültürel, askeri ve daha birçok alanda bilgiye ulaşmak mümkündür.

\section{MERSIN TARIHINE İLIŞKİN OSMANLI ARŞIVINDE BULUNAN KAYITLAR}

\section{Mühimme Defterleri}

Dîvân-1 Hümâyûn toplantılarında müzâkere edilen dâhilî ve haricî meselelere ait önemli siyasî, askerî, içtimaî ve iktisadî kararların kaydedildiği bu defterlere “Mühimme Defterleri” adı verilmiştir. Osmanlı Arşivi'nde 961-1333/1553-1915 tarihleri arasında tutulmuş 419 adet Mühimme defteri mevcuttur. (Başbakanlık Osmanlı Arşiv Rehberi, 2010: 7). Bazı istisnalar dışında Mühimme defterleri 
kaleme alındıkları sadrazam ve reisülküttabın devrini belirten bir başlıkla başlar (Kütükoğlu, 2006: 520-523). Cumhurbaşkanlığı Osmanlı Arşivi’ndeki Dîvân (Beylikçi) Kalemi ve bağlı birimlerine ait Mühimme defterleri içinde Mersin hakkında bilgi veren defterlerin kodu, açılımı ve kayıt sayıları aşağıda listelenmiştir.

$\mathrm{Bu}$ belge örneklerinde tımar emri, ulak hükmü, cami yapımı için masraflar hakkında çeşitli konularda veriler mevcuttur.

Tablo 1. Mersin Tarihine İlişkin Mühimme Defterleri

\begin{tabular}{|c|l|c|}
\hline KODU & \multicolumn{1}{|c|}{ AÇILIMI } & $\begin{array}{c}\text { KAYIT } \\
\text { SAYISI }\end{array}$ \\
\hline A.DVNS.MHM.d & $\begin{array}{l}\text { 989 Numaralı Dîvân-1 Hümâyûn Defterleri } \\
\text { Kataloğundaki Mühimme Defterleri }\end{array}$ & 8 \\
\hline
\end{tabular}

Kaynak: Cumhurbaşkanlığı Osmanlı Arşivi

\section{Divân-ı Hümâyûn ve Bâb-ı Âsafi Belgeleri}

Osmanlı Devleti'nde Bâb-1 Hümayun padişah kapısı ve saray1, Bâb-1 Âsafî sadrazam kapısı ve sarayı anlamında kullanılmıştır. (İpşirli, 1991: 386-389). Divân-1 Hümayun toplantılarının tamamen terk edilmesinden sonra bütün devlet işleri Bâb-1 Âsafî'de görülmeye başlanmıştır. Bâb-1 Âsafî, XVIII. yüzyıl sonlarına kadar bu faaliyetini sürdürmüştür. Bu tarihten sonra "Bâb-1 Âlî" tabiri Bâb-1 Âsafî'nin yerine kullanılmıştır (Başbakanlık Osmanlı Arşiv Rehberi, 2010: 183). Cumhurbaşkanlığı Osmanlı Arşivi'ndeki Divân-1 Hümâyûn ve Bâb-1 Asâfi belgeleri içinde Mersin hakkında bilgi veren belgelerin kodu, açılımı ve kayıt sayıları aşağıda listelenmiş̧ir.

Tablo 2. Mersin Tarihine İlişkin Divân-1 Hümâyûn ve Bâb-1 Âsafi Belgeleri

\begin{tabular}{|l|l|c|}
\hline \multicolumn{1}{|c|}{ KODU } & \multicolumn{1}{|c|}{ AÇILIMI } & \begin{tabular}{c}
\multicolumn{1}{|c|}{ KAYIT } \\
SAYISI
\end{tabular} \\
\hline A.\}AMD. & Bâb-1 Asâfi Âmedî Kalemi & 6 \\
\hline A.\}DVN. & Bâb-1 Asâfi Dîvân-1 Hümâyûn Kalemi & 5 \\
\hline A.\}DVN.DVE. & $\begin{array}{l}\text { Bâb-1 Asâfi Divân-1 Hümâyûn Düvel-i Ecnebiye } \\
\text { Kalemi }\end{array}$ & 1 \\
\hline A.\}DVN.MHM. & Bâb-1 Asâfi Divân-1 Hümâyûn Mühimme Kalemi & 5 \\
\hline
\end{tabular}

Kaynak: Cumhurbaşkanlığı Osmanlı Arşivi 
$\mathrm{Bu}$ belgelerde konsolos, papaz, sefaret memurlarının tayin, nişan takdimi gibi işleri, iskelede çalışan beratlı tüccarların nişanları, vs. gibi çok çeşitli konularda veriler bulmak mümkündür.

\section{Sadâret Defterleri ve Sadâret Mektûbî Belgeleri}

Çeşitli makam ve kişilere Sadrazam tarafından yazılan resmi yazılar ve mektuplar ile önemli işlere dair emirler ve buyruldular bu kalem tarafından yazııır. Kalemin başında "Mektubi Efendi" adı verilen Sadrazam Mektupçusu da denilen görevli vardır. (Başbakanlık Osmanlı Arşiv Rehberi, 2010: 288) Cumhurbaşkanlığı Osmanlı Arşivi'ndeki Sadâret Defterleri ve Sadâret Mektûbî Kalemi tasnifi içinde Mersin hakkında bilgi veren defter ile belgelerin kodu, açılımı ve kayıt sayıları aşağıda listelenmiştir.

Tablo 3. Mersin Tarihine İlişkin Sadâret Defterleri ve Sadâret Mektûbî Belgeleri

\begin{tabular}{|l|l|c|}
\hline \multicolumn{1}{|c|}{ KODU } & \multicolumn{1}{|c|}{ AÇILIMI } & $\begin{array}{c}\text { KAYIT } \\
\text { SAYISI }\end{array}$ \\
\hline A.\}d... & Sadâret Defterleri & 1 \\
\hline A.\}DVN.MKL. & Sadâret Dîvân Mukavelenameler & 7 \\
\hline A.\}MKT.DV.. & Sadâret Mektûbî Kalemi Deavi Evrâk1 & 66 \\
\hline A.\}MKT.MHM. & Sadâret Mektûbî Mühimme Kalemi Evrâk1 & 16 \\
\hline A.\}MKT.MVL. & Sadâret Mektûbî Kalemi Meclis-i Vâlâ Evrâk1 & 36 \\
\hline A.\}MKT.NZD. & Sadâret Mektûbî Kalemi Nezâret ve Deva'ir Evrâk1 & 53 \\
\hline A.\}MKT.UM.. & Sadâret Mektûbî Kalemi Umum Vilayat Evrâk1 & 2 \\
\hline A.\}MTZ.(04) & Sadâret Eyalet-i Mümtaze Bulgaristan Evrâk1 & 4 \\
\hline A.\}MTZ.(05) & Sadâret Eyalet-i Mümtaze Misır Evrâk1 & 1 \\
\hline A.\}MTZ.SM.. & Sadâret Eyalet-i Mümtaze Sisam Evrâk1 & \\
\hline
\end{tabular}

Kaynak: Cumhurbaşkanlığı Osmanlı Arşivi

$\mathrm{Bu}$ tasniflerin içinde iskele, karakol, demiryolu, karayolu yapımı ve tamiri gibi imar faaliyetleri maden sevki, iskeleden ihraç ve ithal olunan mallar, muhacirlerin iskânı, vakıflara ait arazilerin kiraya verilmesi, salgın hastalıklar, karantina, asayiş, yabanc1 şirketlere verilen izinler, bac ve gümrük vergileri, çeşitli konularda verilen ruhsatlar, orman ve tuzladan çıkarılan kereste ve tuzun ihracatı, imtiyaz, Ermeni olayları, vs. gibi çok çeşitli konulara dair belgeler bulunmaktadır. 


\section{Ali Emirî Tasnifi Belgeleri}

Ali Emirî Efendi başkanlığında bir heyet tarafından 1918-1921 seneleri arasında gerçekleştirilen bir tasnif olmasından dolayı "Ali Emirî Tasnifi" adı verilmiştir. Osmanlı Devleti'nin kuruluş yıllarından başlayarak Sultan Abdülmecid zamanına kadar gelen vesikaları ihtiva eder. Ali Emirî Tasnifi'nde siyasî ve askerî konulara ait belgeler; timar ve zeâmet tevcihleri; yabancı ülkelerle münasebetler; Dîvân-1 Hümâyûn'a ait meseleler, maarif, inşa ve tamir gibi konularda vesikalar bulunmaktadır. (Başbakanlık Osmanlı Arşiv Rehberi, 2010: 418). Bu kayıtlarda mukataa kayıtları ve tımar tevcihleri ile ilgili belgeler mevcuttur. Cumhurbaşkanlığı Osmanlı Arşivi’ndeki Ali Emirî Tasnifi belgeleri içinde Mersin hakkında bilgi veren belgelerin kodu, açılımı ve kayıt sayıları aşağıda listelenmiştir.

Tablo 4: Mersin Tarihine İlişkin Ali Emirî Tasnifi Belgeleri

\begin{tabular}{|l|l|c|}
\hline \multicolumn{1}{|c|}{ KODU } & \multicolumn{1}{c|}{ AÇILIMI } & $\begin{array}{c}\text { KAYIT } \\
\text { SAYISI }\end{array}$ \\
\hline AE.SABH.I.. & Ali Emirî Abdülhamid I & 2 \\
\hline AE.SMHD.I.. & Ali Emirî Mahmud I & 1 \\
\hline AE.SMHD.II.. & Ali Emirî Mahmud II & 3 \\
\hline AE.SMMD.IV. & Ali Emirî Mehmed IV & 4 \\
\hline AE.SMST.II. & Ali Emirî Mustafa I & 1 \\
\hline AE.SMST.III & Ali Emirî Mustafa III & 3 \\
\hline AE.SSLM.III & Ali Emirî Selim III & 1 \\
\hline
\end{tabular}

Kaynak: Cumhurbaşkanlığı Osmanlı Arşivi

\section{Bâb-ı Âlî Evrâk Odası Belgeleri}

Bab-1 Ali Evrâk Odasının çalışma sahası tarih olarak 1839(1255)-1922(1341) Tanzimat'la İstanbul Hükümeti'ne kadar geçen seksen üç yıllık zamanı kapsayan Türk siyasi, içtimai, iktisadi, kültürel ve diğer sahalardaki tarihi gelişimi ortaya koyan çok önemli bir devirdir (Sertoğlu, 1955: 51). Bab-1 Âlî Evrâk Odası Tanzimat'tan sonra Bab-1 Âlî'deki evrâk akışını sağlamış, nihayet 24 Şevval 1277/5 Mayıs 1861 tarihinde çıkan nizamnâme ile imparatorluğun sonuna kadar devam edecek bir müessese hâlini almıştır. Her ne kadar odada başlangıçtan sonuna kadar Sadâret'ten yazılan tezkire ve tahrirâtın kayıt ve saklama işleri yürütülmüşse de, Şevval 1309 / Nisan 1892 tarihinden itibaren farklı bir metotla bu işlemler yerine getirilmeye başlanmıştır (Başbakanlık Osmanlı Arşiv Rehberi, 2010: 326). Cumhurbaşkanlığı Osmanlı Arşivi'ndeki Bâb-1 Âlî Evrâk Odası 
Belgeleri içinde Mersin hakkında bilgi veren belgelerin kodu, açılımı ve kayıt sayıları aşağıda listelenmiştir.

Tablo 5. Mersin Tarihine İlişkin Bâb-1 Âlî Evrâk Odası Belgeleri

\begin{tabular}{|l|l|c|}
\hline KODU & \multicolumn{1}{|c|}{ AÇILIMI } & $\begin{array}{c}\text { KAYIT } \\
\text { SAYISI }\end{array}$ \\
\hline BEO & Bâb-1 Âlî Evrâk Odası & 739 \\
\hline
\end{tabular}

Kaynak: Cumhurbaşkanlığı Osmanlı Arşivi

$\mathrm{Bu}$ tasnif içindeki belgeler diğer tasniflere göre sayıca ve içerik olarak daha fazla olmakla birlikte Hâriciye, Rüsûmât, Evkâf, Bahriye, Posta Telgraf, Adliye, Mülkiye, Ticâret ve Nafia, Mâliye, Sihhiye, Harbiye, Orman ve Maadin ve Zirâât, Maârif, Zabtiye gibi kurumların ilgili alanlarda Mersin idaresiyle olan yazışmalarını içeren konulardadır.

\section{Muallim Cevdet Tasnifi Belgeleri}

1931 yılında Mâliye deposundaki bir kısım belgelerin Bulgaristan'a satılması üzerine 8 Ekim 1932 tarihli İcra Vekilleri Heyeti kararıyla Muallim Cevdet'in başkanlığında yeni bir tasnif heyeti oluşturulmuştur. Kilisli Muallim Rıfat, emekli bazı devlet memurları ve tarih uzmanı kimseler bu heyette yer almıştır. Muallim Cevdet 1935 'te istifa ederek ayrıldığı hâlde tasnif 1937 yılına kadar sürmüştür. "Cevdet Tasnifi" adı verilen bu çalışmada belgeler konularına göre tasnif edilmiş, fakat kronolojik olarak kataloglarına geçirilmemiştir. Bu tasnif, 17 ana bölüm altında 960-1322/1553-1904 tarihleri arasındaki kayıtları ihtiva eden 216.572 adet belgeden oluşup 87 adet kataloğu mevcuttur (Başbakanlık Osmanlı Arşiv Rehberi, 2010: 420). Cumhuriyet ile birlikte Türkiye'de tarihi belgelerin bir değer taşıdığı bilincinin ortaya çıkmasında Muallim Cevdet'in önemli rolü olmuştur. Bu sebeple Türk arşivciliğinin kurucusu sayılmıştır (Sayar, 2005: 313314). Cumhurbaşkanlığı Osmanlı Arşivi’ndeki Muallim Cevdet Tasnifi belgeleri içinde Mersin hakkında bilgi veren belgelerin kodu, açılımı ve kayıt sayıları aşağıda listelenmiştir.

Tablo 6. Mersin Tarihine İlişkin Muallim Cevdet Tasnifi Belgeleri

\begin{tabular}{|l|l|c|}
\hline \multicolumn{1}{|c|}{ KODU } & \multicolumn{1}{|c|}{ AÇILIMI } & $\begin{array}{c}\text { KAYIT } \\
\text { SAYISI }\end{array}$ \\
\hline C..BLD. & Cevdet Belediye & 1 \\
\hline C..DH.. & Cevdet Dâhiliye & 1 \\
\hline C..EV.. & Cevdet Evkâf & 2 \\
\hline C..HR.. & Cevdet Hâriciye & 2 \\
\hline
\end{tabular}




\begin{tabular}{|l|l|l|} 
C..IKTS & Cevdet İktisat & 2 \\
\hline C..ML.. & Cevdet Mâliye & 1 \\
\hline C..SH.. & Cevdet Sihhiye & 3 \\
\hline C..TZ.. & Cevdet Timar & 1 \\
\hline C..ZB.. & Cevdet Zabtiye & 1 \\
\hline
\end{tabular}

Kaynak: Cumhurbaşkanlığı Osmanlı Arşivi

Söz konusu bu kataloglar vakıf, hâriciye, iktisat, maliye, zabtiye, sıhhiye, tımar, evkâf, belediye, dâhiliye olarak tasnif edilmekle beraber ilgili konularda Mersin'e ait bilgiler bulmak mümkündür.

\section{Dâhiliye Nezâreti Belgeleri}

Osmanlı Devleti'nin kuruluşundan itibaren ülke içinde huzur ve asayişin sağlanması ve bunun için görevliler tayin edilmesi devletin en temel vazifelerinden biri olmuştur. Bu konuda ise padişahın en birinci yarımcısı klasik dönemde vezir-i azam iken post-klasik dönem ve sonrasında ise Sadrazam adını almıştır. Tanzimat dönemi bürokratik reform hareketleri çerçevesinde merkez ve taşrada ülke genelinde gerçekleştirilen kurumsallaşma çabasının en önemli ayağı devlet idâresinin modernleşme bağlamında yönetim merkezinin sarayın dışına çıkarılarak Sadâret kurumunun kurulması ve dahili ve harici olarak devlet işlerinin birbirinden ayrılmasıydı. Bu bağlamda ilk oluşturulan kurumlar nezâretler ve meclisler olmuştur. 1836'da ilk oluşturulan nezâret Dâhiliye Nezâreti olmuştur (Akyıldız, 1993: 26-29, 66-69, 179-290. Çadırc1, 2007: 173209. İpşirli, 1993: 414-416). Gerek Sadâret'e bağlı olduğu dönemde, gerekse müstakil olduğu dönemde, Dâhiliye Nezâreti'nin görev alanı, devletin iç işleriyle alakalı konular olmuştur. Emniyet-i Umûmiye, Muhâberât-ı Umûmiye, Matbûât, Hey'et-i Teftişiye gibi kalemler tarafından işleri yürütülen Dâhiliye Nezâreti'nin bu birimlere ait Evrâk grupları, memur tayinleri, asker ve jandarma tensîki, çekirge istilası, sansür, çete faaliyetleri, mezhep çatışmaları, asayiş vukuatı, tabiî âfetler ve zarar gören ahaliye yapılan yardımlar, surre alaylarının hazırlıkları, arkeolojik kazı izinleri vb. konuları ihtiva eder (Başbakanlık Osmanlı Arşiv Rehberi, 2010: 359). Osmanlı Arşivi'ndeki Dâhiliye Nezâreti belgeleri içinde Mersin hakkında bilgi veren belgelerin kodu, açılımı ve kayıt sayıları aşağıda listelenmiştir.

Tablo 7: Mersin Tarihine İlişkin Dâhiliye Nezâreti Belgeleri

\begin{tabular}{|l|l|c|}
\hline \multicolumn{1}{|c|}{ KODU } & \multicolumn{1}{|c|}{ AÇILIMI } & $\begin{array}{c}\text { KAYIT } \\
\text { SAYISI }\end{array}$ \\
\hline DH.DACZ & Dâhiliye Nezâreti Darülaceze Müdüriyeti & 1 \\
\hline
\end{tabular}




\begin{tabular}{|c|c|c|}
\hline DH.EUM.1.Şb & $\begin{array}{l}\text { Dâhiliye Nezâreti Emniyet-i Umûmiye Birinci } \\
\text { Şube }\end{array}$ & 1 \\
\hline DH.EUM.2.Sb & $\begin{array}{l}\text { Dâhiliye Nezâreti Emniyet-i Umûmiye ikinci } \\
\text { Şube }\end{array}$ & 37 \\
\hline DH.EUM.3.Sb & $\begin{array}{l}\text { Dâhiliye Nezâreti Emniyet-i Umûmiye üçüncü } \\
\text { Sube }\end{array}$ & 28 \\
\hline DH.EUM.4.Sb & $\begin{array}{l}\text { Dâhiliye Nezâreti Emniyet-i Umûmiye } \\
\text { Dördüncü Sube }\end{array}$ & 1 \\
\hline DH.EUM.5.Sb & $\begin{array}{l}\text { Dâhiliye Nezâreti Emniyet-i Umûmiye } \\
\text { Beşinci Şube }\end{array}$ & 67 \\
\hline DH.EUM.6.Sb & $\begin{array}{l}\text { Dâhiliye Nezâreti Emniyet-i Umûmiye Altıncı } \\
\text { Şube }\end{array}$ & 13 \\
\hline DH.EUM.ADL. & $\begin{array}{l}\text { Dâhiliye Emniyet-i Umûmiye Takîbât-1 } \\
\text { Adliye Kalemi Evrâk1 }\end{array}$ & 1 \\
\hline DH.EUM.AYŞ. & $\begin{array}{l}\text { Dâhiliye Emniyet-i Umûmiye Asâyiş Kalemi } \\
\text { Evrâk1 }\end{array}$ & 7 \\
\hline DH.EUM.ECB. & $\begin{array}{l}\text { Dâhiliye Nezâreti Emniyet-i Umûmiye Ecânib } \\
\text { Kalemi }\end{array}$ & 4 \\
\hline DH.EUM.EMN. & $\begin{array}{l}\text { Dâhiliye Emniyet-i Umûmiye Emniyet Şubesi } \\
\text { Evrâk1 }\end{array}$ & 26 \\
\hline DH.EUM.KLH. & $\begin{array}{l}\text { Dâhiliye Nezâreti Emniyet-i Umûmiye } \\
\text { Kalem-i Husûsî }\end{array}$ & 1 \\
\hline DH.EUM.KLU. & $\begin{array}{l}\text { Dâhiliye Nezâreti Emniyet-i Umûmiye Kalemi } \\
\text { Umûmî }\end{array}$ & 4 \\
\hline DH.EUM.LVZ. & $\begin{array}{l}\text { Dâhiliye Nezâreti Emniyet-i Umûmiye } \\
\text { Levâzım Kalemi }\end{array}$ & 45 \\
\hline DH.EUM.MEM. & $\begin{array}{l}\text { Dâhiliye Emniyet-i Umûmiye Memûrîn } \\
\text { Kalemi Evrâk1 }\end{array}$ & 42 \\
\hline DH.EUM.MH.. & $\begin{array}{l}\text { Dâhiliye Emniyet-i Umûmiye Muhâsebe } \\
\text { Kalemi Evrâk1 }\end{array}$ & 115 \\
\hline DH.EUM.MTK. & $\begin{array}{l}\text { Dâhiliye Emniyet-i Umûmiye Muhâberât ve } \\
\text { Tensikât Müdüriyeti Evr. }\end{array}$ & 24 \\
\hline DH.EUM.PMC. & $\begin{array}{l}\text { Dâhiliye Nezâreti Emniyet-i Umûmiye Polis } \\
\text { Mecmûası }\end{array}$ & 5 \\
\hline DH.EUM.SCL. & $\begin{array}{l}\text { Dâhiliye Emniyet-i Umûmiye Sicil Kalemi } \\
\text { Evrâk1 }\end{array}$ & 2 \\
\hline DH.EUM.SSM. & $\begin{array}{l}\text { Dâhiliye Nezâreti Emniyet-i Umûmiye } \\
\text { Seyrüsefer Kalemi }\end{array}$ & 89 \\
\hline DH.EUM.THR. & $\begin{array}{l}\text { Dâhiliye Emniyet-i Umûmiye Tahrirat Kalemi } \\
\text { Evrâk1 }\end{array}$ & 8 \\
\hline
\end{tabular}




\begin{tabular}{|l|l|c|} 
DH.EUM.VRK. & $\begin{array}{l}\text { Dâhiliye Emniyet-i Umûmiye Evrâk Odas1 } \\
\text { Kalemi Evrâk1 }\end{array}$ & 9 \\
\hline DH.H... & Dâhiliye Nezâreti Hukuk Evrâk1 & 9 \\
\hline DH.HMŞ. & Dâhiliye Nezâreti Hukuk Müşavirliği Evrâk1 & 1 \\
\hline DH.İ.UM & Dâhiliye Nezâreti idâre-i Umûmiye Evrâk1 & 46 \\
\hline DH.İ.UM.EK. & Dâhiliye Nezâreti idâre-i Umûmiye Ekleri & 36 \\
\hline DH.İD.. & Dâhiliye Nezâreti idâre & 84 \\
\hline DH.KMS. & $\begin{array}{l}\text { Dâhiliye Nezâreti Dâhiliye Kalem-i Mahsûs } \\
\text { Evrâk1 }\end{array}$ & 36 \\
\hline DH.MB..HPS. & $\begin{array}{l}\text { Dâhiliye Nezâreti Mebâni-i Emirîye- } \\
\text { Hapishaneler Müdüriyeti Evrâk1 }\end{array}$ & 35 \\
\hline DH.MB..HPS.M. & $\begin{array}{l}\text { Dâhiliye Nezâreti Mebâni-i Emirîye- } \\
\text { Hapishaneler Müdüriyeti Müteferrik Evrâk1 }\end{array}$ & 19 \\
\hline DH.MKT. & Dâhiliye Nezâreti Mektûbî Kalemi & 1079 \\
\hline DH.MTV. & Dâhiliye Nezâreti Mütenevvia Evrâk1 & 34 \\
\hline DH.MUİ. & Dâhiliye Muhâberât-1 Umûmiye İdâresi Evr. & 52 \\
\hline DH.SAİD.MEM & $\begin{array}{l}\text { Dâhiliye Nezâreti Sicill-i Ahvâl İdâre-i } \\
\text { Umûmiyesi }\end{array}$ & 1 \\
\hline DH.SAİD.d... & $\begin{array}{l}\text { Dâhiliye Nezâreti Sicill-i Ahvâl Defterleri } \\
\text { Fihristi }\end{array}$ & 46 \\
\hline DH.SN..THR. & $\begin{array}{l}\text { Dâhiliye Nezâreti Sicill-i Nüfus Tahrirat } \\
\text { Kalemi }\end{array}$ & 17 \\
\hline DH.SYS. & Dâhiliye Nezâreti Siyasi Kısım Evrâk1 & 8 \\
\hline DH.ŞFR. & Dâhiliye Nezâreti Şifre Evrâk1 & 483 \\
\hline DH.TMIK.M.. & $\begin{array}{l}\text { Dâhiliye Nezâreti Tesri-i Muamelat ve Islahat } \\
\text { Komisyonu Muamelat }\end{array}$ & 582 \\
\hline DH.TMIK.S.. & $\begin{array}{l}\text { Dâhiliye Nezâreti Tesrî-i Muâmelât ve Islâhat } \\
\text { Komisyonu }\end{array}$ & 33 \\
\hline DH.UMVM & $\begin{array}{l}\text { Dâhiliye Nezâreti Umûr-1 Mahalliye ve } \\
\text { Vilâyât Müdürlügü Evrâk1 }\end{array}$ & 25 \\
\hline
\end{tabular}

Kaynak: Cumhurbaşkanlığı Osmanlı Arşivi

Mersin Limanı'na giriş çıkan gemiler, liman işleri, savaş sürecinde yabancı devletlerin bölgedeki faaliyetleri, konsolosluk işlemleri, yabancı tebaa ile ilgili yazışmalar, asayişle ilgili çeşitli konular, suç istatistik cetvelleri, memurların göreve atanma ve tayinleri, maaş-harcırah ödemeleri, bölge içindeki idari merkez kaymalar, idari düzenlemeler, Mersin Limanı'ndan yapılan ihracat, salgın hastalıklar, fabrika ve şirket inşaları, hapishane kayıtları ve cetvelleri, siyasi evrâklar, şifreli yazışmalar, sicil-i ahvâl kayıtları, vb. çok çeşitli konular hakkında bu tasnifte belgeler bulmak mümkündür. Dahiliye Nezâreti yazışmaları diğer pek 
çok tasnife göre çeşitliliği ve niceliği daha fazla olan bir konu yelpazesine sahiptir. Bunun sebebi, özellikle bu nezâretin devletin jurnal teşkilatı gibi çalışması ve hemen her konu ile ilgili yazışmaların yürütülmesidir.

\section{Hatt-ı Hümâyûn Tasnifi}

Hatt-1 hümayun; Osmanlı diplomatiğinde padişahın kendi el yazısı ile yazılmış emirler için kullanılan bir tabirdir ( Kütükoğlu, 1997: 485-488). Hatt-1 hümayunlar, sadrazamların tahrirî olarak ve kısaca arz ettikleri meseleler dolayısıyla telhis denilen kâğıdın üzerine yazıldığı gibi, doğrudan doğruya elinden de çıkabilirdi. Sultan Üçüncü Murad dönemine kadar padişahlar nadiren ve sınırlı konularla ilgili yazılı emirler verilirken, bu dönemden itibaren hatt-1 hümâyûnlar çoğalmıştır. Hatt-1 hümâyûnlarla ilgili ilk tasnif 1883 yılında yapılmış olup, bu tarihte hazırlanan fihrist defterleri 1940 yılına kadar kullanılmıştır (Başbakanlık Osmanlı Arşiv Rehberi, 2010, 421-422). Cumhurbaşkanlığı Osmanlı Arşivi’ndeki Hatt-1 Hümâyûn Tasnifi içindeki kayıtlarına bakıldığında içerisinde Mersin geçen beş kayıt bulunmaktadır. Ancak bunlardan biri Mersin balığı ile ilgilidir. Diğer dört tanesi de 1802-1838 tarihleri arasına aittir. Mersin'in 1830'larda henüz birkaç balıkçı barınağından oluşan köy bile olmadığı düşünüldüğünde bu hatların Çukurova Bölgesindeki Mersin yerleşimi ile ilgili olmama ihtimali yüksektir.

Tablo 8. Mersin Tarihine İlişkin Hatt-1 Hümâyûn Tasnifi

\begin{tabular}{|c|c|c|c|c|c|c|c|}
\hline$\sqcap$ НАТ & 1247 & $48347 \mathrm{~J}$ & 1254 & z & 29 & 1 & $\begin{array}{l}\text { Debre-iZir kazasinda vaki Kücük Boğaz ahalisinin Debreli Süleyman Beyzade Mersin } \\
\text { Bey'i Debreler'e mütesellim edeceğiz diyerek kasabaya hücum etmişlerse de } \\
\text { kovulduklarna dair ilam ve mahzar müsveddesi. a.g.y.tt }\end{array}$ \\
\hline HAT & 1486 & 3 & 1218 & M & 10 & 1 & $\begin{array}{l}\text { Karadeniz'den İstanbul'a gelen karahavyar, morina, Mersin balığı ve sair balikların balık } \\
\text { tuzlayıclarinna ne sekilde dağttllacağina dair hatt-ı hümayun sureti. }\end{array}$ \\
\hline HAT & 1538 & 37 & 1232 & C & 15 & 1 & $\begin{array}{l}\text { Osman veled-i Omerin çocuksuz olarak vefattyla mahlul kalan Mersin sancağı merkez } \\
\text { nahiyesindeki tımarnin Saray-I Atik teberdarlarndan Hasan'a tevcihi. }\end{array}$ \\
\hline HAT & 407 & 21222 & 1222 & z & 29 & 1 & $\begin{array}{l}\text { Vehhabiler Mersin'e tesallutta bulunmakla Hacca giden olmadığindan ve devlet, Rusya } \\
\text { ile harpte bulunduğundan Vehhabiler üzerine sevk-i askerin harp sonuna birakıldığ ve } \\
\text { Şam Valisi Genç Yusuf Paşa'nın iki bin askerle Hacca gidip gelmesi kararlaştırldiğı } \\
\text { hakkında. a.g.y.tt }\end{array}$ \\
\hline HAT & 407 & 21224 & 1246 & z & 29 & 1 & 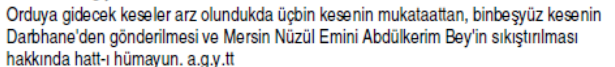 \\
\hline
\end{tabular}

Kaynak: Cumhurbaşkanlığı Osmanlı Arşivi

\section{Hâriciye Nezâreti Belgeleri}

Osmanlı Devleti'nde 1836'da kurulan ve Cumhuriyet döneminde adı "Dışişleri Bakanlığ $"$ " olarak değiştirilen kurumdur (Findley, 1997: 178-180). Reisülküttaplığın yerini Hâriciye Nezâreti'nin alışı her ne kadar bir unvan değişikliği gibi gözükse de zaman içinde idari birimleri oluşturularak kurumsal bir yapı haline getirilmiştir (Akpınar 2014, 66-67).

Hâriciye Nezâreti Arşivi, Tanzimat'la birlikte kurumsallaşan Hâriciye Nezâreti'ne paralel olarak oluşan "merkez arşivi" ile sefaret ve konsolosluklarda oluşan "taşra arşivi" olmak üzere iki grupta toplanmaktadır. Hâriciye Nezâreti 
fonunda, siyasî, hukukî, idarî konulardaki çok önemli meselelerin yanı sıra, ticaret anlaşmaları; sefaret ve şehbenderliklerle yapılan yazışmalar; köle ticaretinin yasaklanması; Sırbistan'daki Müslüman halkın dinî meseleleri; yabancı devlet başkanlarına gönderilen ve onlardan gelen, daha çok doğum, vefat, cülûs, evlilik konularındaki nâmeler; rütbe, nişan ve madalya tevcihleri; sınırların dışında kalan topraklara ait tapu tahkikleri yer alır. (Başbakanlık Osmanlı Arşiv Rehberi, 2010: 379-380). Cumhurbaşkanlığı Osmanlı Arşivi'ndeki Hâriciye Nezâreti Belgeleri içinde Mersin hakkında bilgi veren belgelerin kodu, açılımı ve kayıt sayıları aşağıda listelenmiştir.

Tablo 9. Mersin Tarihine İlişkin Hâriciye Nezâreti Belgeleri

\begin{tabular}{|l|l|c|}
\hline \multicolumn{1}{|c|}{ KODU } & \multicolumn{1}{|c|}{ AÇILIMI } & $\begin{array}{c}\text { KAYIT } \\
\text { SAYISI }\end{array}$ \\
\hline HR.H... & Hâriciye Nezâreti Hukuk Kısmı Evrâk1 & 13 \\
\hline HR.HMŞ.İ̧O. & $\begin{array}{l}\text { Hâriciye Nezâreti Hukuk Müşavirliği İstişare } \\
\text { Odası Evrâk1 }\end{array}$ & 56 \\
\hline HR.İD.. & Hâriciye Nezâreti idâre & 34 \\
\hline HR.IM.. & Hâriciye Nezâreti İstanbul Murahhaslığ1 & 165 \\
\hline HR.MKT. & Hâriciye Nezâreti Mektûbî Kalemi Evrâk1 & 50 \\
\hline HR.SAİ. & $\begin{array}{l}\text { Hâriciye Nezâreti Sicill-i Ahvâl İdâre-i } \\
\text { Umûmiyesi Belgeleri }\end{array}$ & 2 \\
\hline HR.SFR.04.. & Hâriciye Nezâreti Paris Sefareti Belgeleri & 11 \\
\hline HR.SFR.1... & Hâriciye Nezâreti Atina Sefareti & 11 \\
\hline HR.SFR.3... & Hâriciye Nezâreti Belgrat Sefareti & 22 \\
\hline HR.SYS. & Hâriciye Nezâreti Siyasî Kısmı Belgeleri & 138 \\
\hline HR.TH.. & Hâriciye Nezâreti Tahrîât-1 Hâriciye Odası & 154 \\
\hline HR.TO.. & Hâriciye Nezâreti Tercüme Odası Belgeleri & 28 \\
\hline HR.UHM. & $\begin{array}{l}\text { Hâriciye Nezâreti Umûr-1 Hukûk-1 Muhtâlita } \\
\text { Müdüriyeti }\end{array}$ & 21 \\
\hline
\end{tabular}

Kaynak: Cumhurbaşkanlığı Osmanlı Arşivi

$\mathrm{Bu}$ tasnifte yabancı tebaanın Mersin'de yürüttüğü ticari işlemler, gümrük işleri, Mersin yerel idaresi ile yabancı devletlerin yazışmaları, ihraç ve ithal edilen mallar, konsolosluk yazışmaları, Mersin Limanı'nın ıslahı ve yeniden yapılandırılması, limana her türlü giriş çıkışlar, dış dünyayla kurulan bütün bağlantılarla ilgili çok çeşitli konularda belgeler bulmak mümkündür. Hâriciye Nezâreti tasnifi de en az Dâhiliye Nezâreti tasnifi kadar geniş bir veri dağarcığına sahiptir. 


\section{İrâdeler}

Arapça bir kelime olan İrâde "dileme, isteme; emir, ferman" manalarını taşırdı. İrâde-i Seniyye ise "padişah emri" anlamına gelmektedir (Kütükoğlu, 2000: 391-392). 1832 senesinden önce, herhangi bir mesele hakkında padişahın yorumuna gerek duyulduğunda, konunun özeti padişaha sunulurdu. Padişah, "arz tezkiresi" veya "telhîs" denilen bu özeti okuyarak konu hakkındaki fikrini belge üzerinde beyan ederdi. Meşrutiyetten sonra padişah sadece vekiller heyeti kararlarını onaylamış ve buna da irade denilmiştir ( Başbakanlık Osmanlı Arşiv Rehberi, 2010: 299-300). Osmanlı Arşivi'ndeki irade belgeleri içinde Mersin hakkında bilgi veren belgelerin kodu, açılımı ve kayıt sayıları aşağıda listelenmiştir.

Tablo 10. Mersin Tarihine İlişskin İrâde Tasnifleri

\begin{tabular}{|l|l|c|}
\hline \multicolumn{1}{|c|}{ AÇILIMI } & $\begin{array}{c}\text { KAYIT } \\
\text { SAYISI }\end{array}$ \\
\hline HH.İ. & Hazîne-i Hâssa İrâdeler & 6 \\
\hline İ..AS.. & İrâde -i Askeri & 7 \\
\hline İ..AZN. & İrâde -i Adliye ve Mezahib & 16 \\
\hline İ..DA.. & İrâde -i Dîvân-1 Ahkâm-1 Adliye & 1 \\
\hline İ..DFE. & İrâde -i Defter-i Hâkânî & 2 \\
\hline İ..DH.. & İrâde -i Dâhiliye & 79 \\
\hline İ..DUİT & İrâde- Dosya Usulü İrâdeler & 21 \\
\hline İ..EV.. & İrâde - Evkâf & 6 \\
\hline İ..HB.. & İrâde - Harbiye & 11 \\
\hline İ..HR.. & İrâde - Hâriciye & 19 \\
\hline İ..HUS. & İrâde - Husûsî & 30 \\
\hline İ..İMT. & İrâde - İmtiyâzât ve Mukâvelât & 1 \\
\hline İ..MBH. & İrâde - Mabeyn-i Hümâyûn & 1 \\
\hline İ..ML.. & İrâde - Mâliye & 1 \\
\hline İ..MMS. & İrâde - Meclis-i Mahsûs & 13 \\
\hline İ...MTZ.(05) & İrâde - Mısır İrâdeleri & 1 \\
\hline İ...MVL. & İrâde - Meclis-i Vâlâ & 23 \\
\hline İ..OM.. & İrâde - Orman ve Maadin & 1 \\
\hline İ..PT.. & İrâde - Telgraf ve Posta & 5 \\
\hline İ..RSM. & İrâde - Rüsûmât & 12 \\
\hline
\end{tabular}




\begin{tabular}{|c|c|c|}
\hline İ..ŞD.. & İrâde - Şûrâ-yı Devlet & 12 \\
\hline İ..TAL. & İrâde - Taltifât & 39 \\
\hline İ..TKS. & İrâde - Tekâüd Sandı̆̆ı & 3 \\
\hline İ..TNF. & İrâde - Ticâret ve Nafia & 1 \\
\hline İ..TZT. & İrâde - Ticâret ve Zirâât & 1 \\
\hline İE.BH.. & İbnülemin Bahriye & 3 \\
\hline İE.ML.. & İbnülemin Mâliye & 1 \\
\hline İE.SM.. & İbnülemin Saray Mesâlihi & 1 \\
\hline İE.TCT. & İbnülemin Tevcîhât & 2 \\
\hline
\end{tabular}

Kaynak: Cumhurbaşkanlığı Osmanlı Arşivi

İrâdeler tasnifinde Mersin'le ilgili dâhiliye, hâriciye, maliye, adliye, askeriye, harbiye, evkâf, imtiyaz, ticaret ve ziraat, bahriye gibi çeşitli alanlarda çok sayıda belge bulmak mümkündür. Bu tasnifte de dâhiliye iradelerinin sayıca daha fazla oluşu dikkat çekmektedir.

\section{Mâliyeden Müdevver Defterler Tasnifi}

Mâliye Bakanlığı'ndan 1945 yılında yığın hâlinde devralınan 26.000'e yakın defterin tasnifidir. Muhtelif Mâliye kalemlerine ait defterler olduğu gibi, arazi tahriri, saray, yeniçeri, maaş, aylık ve ulufeler vs. gibi diğer cins defterleri de içermektedir. Defterler, 830/1427 yılında başlayıp 1346/1927 yılına kadar gelir. Tasnifteki son defterin sıra numarası 23.138'dir (Başbakanlık Osmanlı Arşiv Rehberi, 2010: 266). Osmanlı Arşivi'ndeki Mâliyeden Müdevver Defterler tasnifi içinde Mersin hakkında bilgi veren defterlerin kodu, açılımı ve kayıt sayıları aşağıda listelenmiştir.

Tablo 11. Mersin Tarihine İlişkin Mâliyeden Müdevver Defterler Tasnifi

\begin{tabular}{|l|l|c|}
\hline KODU & \multicolumn{1}{|c|}{ AÇILIMI } & $\begin{array}{c}\text { KAYIT } \\
\text { SAYISI }\end{array}$ \\
\hline MAD.d. & Mâliyeden Müdevver Defterler & 16 \\
\hline
\end{tabular}

Kaynak: Cumhurbaşkanlığı Osmanlı Arşivi

\section{Maârif Nezâreti}

Tanzimat ile birlikte Osmanlı Devleti'nde önce 1261/1845'te Maârif Meclisi, 1273/1857'de de Maârif Nezâreti kurulmuştur. Tanzimat'nn en önemli gerekliliklerinden biri olan eğitim alanında kurumsallaşma bu gelişmelerle gerçekleştirilmiş ve zamanla altı doldurulmaya çalışılmıştır (Akyıldız 2003: 246250). Osmanlı Arşivi'nde Maârif Nezâreti belgelerinin içerisinde Maârif Meclisi 
dönemine ait belgelere de rastlanmaktadır. Osmanlı Arşivi'ndeki Maârif Nezâreti Defterleri içinde Mersin hakkında bilgi veren belgelerin kodu, açılımı ve kayıt sayıları aşağıda listelenmiştir.

Tablo 12. Mersin Tarihine İlişskin Maârif Nezâreti Tasnifi

\begin{tabular}{|l|l|c|}
\hline \multicolumn{1}{|c|}{ KODU } & \multicolumn{1}{|c|}{ AÇILIMI } & $\begin{array}{c}\text { KAYIT } \\
\text { SAYISI }\end{array}$ \\
\hline MF.İBT & Maârif Nezâreti Tedrisât-1 İbtidâiye Kalemi & 117 \\
\hline MF.MKT & Maârif Nezâreti Mektûbî Kalemi & 213 \\
\hline
\end{tabular}

Kaynak: Cumhurbaşkanlığı Osmanlı Arşivi

Bu tasnifte yer alan belgelerden yola çıka çıkarak Mersin'deki eğitim tarihi hakkında bilgiler edinmek mümkündür. Okullarda çalışan görevlilerin azil, tayin, maaş gibi işlemleri, öğrencilerle ilgili veriler, durum ve sınav cetvelleri, okulların imar, yapım ve tamir işlemleri, masraflar, gelir ve gider verileri, vs. gibi konularda çok sayıda belge bulunmaktadır. Bunun yanı sıra tasnifte eğitimle ilgili veriler dışında bölge için oldukça önemli olan arkeolojiyle ilgi belgeler de bulunmaktadır. Maârif Nezâreti'nin görev ve sorumluluğu içinde olan eski eserler ve arkeolojik alanlarda kazı ve araştırma yapmak için izin ve ruhsat alınması gibi konularda arkeolojik açıdan zengin bir alt yapıya sahip Mersin'le ilgili çok sayıda belge mevcuttur.

\section{Mâliye Nezâreti}

Osmanlı Maliye Teşkilatı, gelirlerin toplandığı ve masrafların yapıldığı çeşitli kalemlerden oluşmaktaydı. Osmanlı maliyesinin işlerini yapan dairelere "kalem" denilirdi (Yurtseven, 2002: 117). Tanzimat dönemi bürokratik reformu ile başlatılan kurumsallaşma çalışması sonucu Bâb-1 Defteri'den dönüştürülen Mâliye Nezâreti, merkezi yönetimin en önemli ayaklarından biri idi. 28 Şubat 1838'de "Umûr-1 Mâliye Nezâreti" adı ile kurulmuş olan Mâliye Nezâreti'nin başına Nâfiz Paşa getirildi (Akyıldız, 2003: 97). Osmanlı Arşivi'ndeki Mâliye Nezâreti'ne ait tasnif içinde Mersin hakkında bilgi veren defter ve belgelerin kodu, açılımı ve kayıt sayıları aşağıda listelenmiştir.

Tablo 13. Mersin Tarihine İlişkin Mâliye Nezâreti Tasnifi

\begin{tabular}{|l|l|c|}
\hline \multicolumn{1}{|c|}{ KODU } & \multicolumn{1}{|c|}{ AÇILIMI } & $\begin{array}{c}\text { KAYIT } \\
\text { SAYISI }\end{array}$ \\
\hline ML.EEM & Mâliye Nezâreti & 37 \\
\hline ML.MKT.d... & Mâliye Nezâreti Mektûbî Kalemi defterleri & 2 \\
\hline ML.MSF.d... & Mâliye Masârifât Defterleri & 2 \\
\hline
\end{tabular}


\begin{tabular}{l|l|l|} 
ML.VRD.TMT.d... & $\begin{array}{l}\text { Mâliye Vâridât Muhâsebesi Temettuât } \\
\text { Defterleri }\end{array}$ & 1 \\
\hline
\end{tabular}

Kaynak: Cumhurbaşkanlığı Osmanlı Arşivi

Bu tasnifte Mersin'le ilgili gelir-gider kayıtları, bağışlar, ödemeler, masraflar, her türlü mali konulardaki yazışmalar vs. ile ilgili bilgi ve belge bulmak mümkündür.

\section{Meclis-i Vükelâ Mazbataları}

Tanzimat Dönemi merkez teşkilatında yürütülen kurumsallaşma çalışmalarının bir ayağını nezâretler oluştururken, ikinci önemli ayağını da meclisler olmuştur. Nezâretler Tanzimat'ın teknik mekanizması, meclisler ise karar mekanizması olmuştur. $\mathrm{Bu}$ dönemde yapılacak olan tüm reform çalışmalarının kararları Tanzimat meclislerinde görüşülmüş ve sonuca bağlanmıştır. Tanzimat meclisleri arasında en üst düzey danışma meclisi niteliğinde ve nezâretler ile meclisler arası koordinasyonu sağlayan ve son kararı padişaha iletmekle yükümlü olan meclis ise Meclis-i Hass-1 Vükelâ'dır (Akyıldız 2003, 179-185). Meclis-i Vükelâ; devletin iç ve dış siyasetinde tüm konularda üst düzey kararların görüşülüp karara bağlandığı bir meclistir. Bu meclise, "Meclis-i Hâss" veya "Meclis-i Hâss-ı Vükelâ" da denilirdi ki bugünkü manada "Bakanlar Kurulu" demektir (Başbakanlık Osmanlı Arşiv Rehberi, 2010: 334). Osmanlı Arşivi'ndeki Meclis-i Vükelâ Mazbataları içinde Mersin hakkında bilgi veren belgelerin kodu, açılımı ve kayıt sayıları aşağıda listelenmiştir.

Tablo 14: Mersin Tarihine İlişkin Meclis-i Vükelâ Mazbata Kayıtları

\begin{tabular}{|l|l|c|}
\hline KODU & \multicolumn{1}{|c|}{ AÇILIMI } & $\begin{array}{c}\text { KAYIT } \\
\text { SAYISI }\end{array}$ \\
\hline MV. & Meclis-i Vükelâ Mazbataları & 51 \\
\hline
\end{tabular}

Kaynak: Cumhurbaşkanlığı Osmanlı Arşivi

$\mathrm{Bu}$ tasnif içinde Mersin liman giriş-çıkış ve gümrük geçiş işlemleri, şirket nizamnamelerinin tadili, maden ihalelerinin işletme ruhsatları, Mersin'in idari statüsündeki değişiklik ve düzenlemeler, tayin, azil ve atama işlemleri vs. gibi çok çeşitli konularda belgeler mevcuttur.

\section{Meclis-i Vâlâ Evrâkları}

Tanzimat döneminde Osmanlı Merkez Teşkilatı'nda yer alan kurumlardan biri de Meclis-i Vâlâ'dır. 1838'de kurumsallaşan Meclis-i Vâlâ, yapılması düşünülen 
reformların gerçekleştirilebilmesi için kanun ve nizamları hazırlamak ve Dar-1 Şûrâ-yı Babıali, Dar-1 Şûrâ-yı Askeri’nin tanzim ettiği mazbatalara son şeklini vermekle görevliydi (Akyıldız, 2003: 250-251). Yasaları yapma ve düzenleme yetkisinin yanı sıra üst yöneticilerin atanması ve yargılanması görevine de sahipti. Bu nedenle özellikle Tanzimat'tan sonra görev ve sorumluluklarının artması sebebi ile 1861'de "Meclis-i Âlî-i Tanzimat" ve "Meclis-i Ahkâm-ı Adliye" birleştirilerek "Meclis-i Vâlâ-yı Ahkâm-ı Adliye" adı altında bir meclise dönüştürülmüsşür. $\mathrm{Bu}$ meclis idâre, Tanzimat, Adliye adlarıyla üç kısma ayrılmıştır (Başbakanlık Osmanlı Arşiv Rehberi, 2010: 223). Osmanlı Arşivi'ndeki Meclis-i Vâlâ Evrâkları içinde Mersin hakkında bilgi veren belgelerin kodu, açılımı ve kayıt sayıları aşağıda listelenmiştir.

Tablo 15. Mersin Tarihine İlişskin Meclis-i Vâlâ Evrâk Kayıtları

\begin{tabular}{|l|l|c|}
\hline KODU & \multicolumn{1}{|c|}{ AÇILIMI } & $\begin{array}{c}\text { KAYIT } \\
\text { SAYISI }\end{array}$ \\
\hline MVL. & Meclis-i Vâlâ Evrâk1 & 62 \\
\hline
\end{tabular}

Kaynak: Cumhurbaşkanlığı Osmanlı Arşivi

Mersin'le ilgili Meclis-i Vâlâ Evrâkı tasnifinde sağlı, ticaret mahkemesi kurulması, demiryolu yapımı, bataklık alanların kurutulması çalışmaları, imar faaliyetleri, atama ve tayin işlemleri, arazi alım-satımları ile ilgili kararlar, bağışlar, cami, iskele, liman vs. inşa ve tadilat işleri ile ilgili alınan kararlar, çiçek aşısı, vergi ihalesi, gibi çok çeşitli konularda belge bulunmaktadır.

\section{Haritalar}

Haritalar tarih araştırmalarında kullanılması gereken en önemli görsel materyallerin başında yer almaktadır. Özellikle kent tarihi çalışmalarında haritalar biz tarihçilere oldukça geniş veriler sağlamaktadır. Bu nedenle özellikle yerel tarih araştırıcıları için vazgeçilmez kaynaklardır. Bu konuda Osmanlı tarihinde Piri Reis'in çok önemli katkılarının olduğunu söylemek gerekir. Müderris Abdurrahman Efendi Türkiye'de ilk ayrıntılı yeni atlası 1800'lü yıllarda Üsküdar'daki Tabhâne-i Hümâyûn'da basmıştır. Bu atlas, Avrupa'da yapılan atlaslardan faydalanılarak hazırlanmıştır. Haritacılık çalışmaları aslında askerî ihtiyaçlardan doğmuştu. Harp Okulu'nun kuruluşundan sonra Batı bilim ve tekniğine olan yönelim, genç subayların Fransa, İngiltere ve Prusya'ya eğitime gönderilmesi, yurt dışından haritacılıkta uzman kişilerin getirilmesi ile Osmanlı coğrafyasında bu alanda önemli çalışmalar yapılmıştır. Öncelikle 1880'de Erkân1 Harbiye 5. Şubesi'nin kurulması sonrasında bu şubeye Batı Anadolu ve Balkanlar bölgesindeki Türk topraklarının haritalarını yapmak görevi verilmiştir (Başbakanlık Osmanlı Arşiv Rehberi, 2010: 427). Böylece bilimsel anlamda haritacılık çalışmaları yürütülmeye başlanmıştır. En erken tarihli harita 1739 
tarihlidir. Arşivde toplamda 720 adet haritanın bulunduğu bilinmektedir. Osmanlı Arşivi'ndeki haritalar tasnifinde Mersin hakkında bilgi veren haritaların kodu, açılımı ve kayıt sayıları aşağıda listelenmiştir.

Tablo 16. Mersin Tarihine İlişkin Haritalar

\begin{tabular}{|l|l|c|}
\hline KODU & AÇILIMI & $\begin{array}{c}\text { KAYIT } \\
\text { SAYISI }\end{array}$ \\
\hline HRT.h. & Haritalar & 15 \\
\hline
\end{tabular}

Kaynak: Cumhurbaşkanlığı Osmanlı Arşivi

$\mathrm{Bu}$ tasnifte Mersin ve çevresine ilişkin, yol, akarsu, dağ, yerleşim bölgesi; çeşme, kuyu, hanlar; kömür, simli kurşun, karbon, civa, gümüş, bakır, tuz madeni gibi madenleri gösteren; demiryolu, şose, hudutlar, idari harita, sulama haritası, tramvay hattı krokisi gibi çeşitli içerikleri gösterir haritalar mevcuttur.

\section{Plan, Proje ve Krokiler}

Haritalar gibi incelenen mekana ilişkin plan, proje ve krokiler de araştırmanın en önemli görsel kaynaklarıdır. Bu tür görsel kaynakların varlı̆g 1 incelenen sürecin ve mekânın daha canlı yansıtılmasını sağlaması açısından önemlidir. Osmanlı Arşivi'nde bulunan plân, proje ve krokilere ait katalog hazırlanırken, 1311 tarihli Dünya Atlas'ından faydalanılmıştır. Bu haritada Osmanlı Devleti'nin idari yapılanması ve vilayetlerin tespiti mevcuttur. Çizimlerin üzerinde açıklayıcı bilgiler bulunmaktadır. Katalog, Osmanlı Devleti siyasî sınırları içindeki vilayetlerin alfabetik olarak sıralanışına göre numaralanmıştır. 1792-1912 yıllarını içeren ve tasnif edilen toplam malzeme sayısı 1.099'dur (Başbakanlık Osmanlı Arşiv Rehberi, 2010: 428). Cumhurbaşkanlığı Osmanlı Arşivi’ndeki Plan, Proje ve Krokiler içinde Mersin hakkında bilgi veren Plan, Proje ve Krokilerin kodu ve kayıt sayıları aşağıda listelenmiştir.

Tablo 17. Mersin Tarihine İlişkin Plan, Proje ve Krokiler

\begin{tabular}{|l|l|c|}
\hline KODU & \multicolumn{1}{|c|}{ AÇILIMI } & $\begin{array}{c}\text { KAYIT } \\
\text { SAYISI }\end{array}$ \\
\hline PLK.P & Plan, Proje ve Krokiler & 14 \\
\hline
\end{tabular}

Kaynak: Cumhurbaşkanlığı Osmanlı Arşivi

$\mathrm{Bu}$ tasnifte Mersin ve çevresine ait yol planı, yeni yapılacak olan cami planı, liman planı, otel planı, istasyon planı, yol üstünde yapılacak köprülerin planı gibi çizimler mevcuttur. 


\section{Şer'iyye Sicilleri}

Şer'iyye Sicilleri Osmanlı Devleti sınırları içinde yaşayan toplumun tümüyle ilgili gerçekleşen olaylar hakkında kayıtların tutulduğu, mahkeme kararlarının yer aldığı ve idari düzenlemelerle ilgili bilgi veren kaynaklardır (Akgündüz, 1998: 11). Kadı sicilleri, kadı dîvânı, mahkeme kayıtları, sicillât-1 şer'iyye ve yaygın kullanımı ile şer'iyye sicilleri denilen bu defterler kadı veya yardımcısı olan nâibler tarafından tutulmakta ve çok çeşitli konulardaki kayıtları içermektedir. $\mathrm{Bu}$ nedenle özellikle yerel tarih araştırmalarında bu siciller başvurulması gereken en önemli kaynak konumundadır (Uğur, 1988: 8-11).

Mersin'e ait müstakil bir şer'iyye sicili bulunmamaktadır. Bu nedenle uzun bir süre Tarsus'un idari kapsamında bulunmasından dolayı Tarsus Şer'iyye Sicillerinde Mersin ile ilgili kayıtlar yer almaktadır. Tarsus'a ait 284-450 arasında numaralandırılmış 1731-1929 yılları arasını kapsayan toplam 176 adet Şer'iyye Sicil Defteri bulunmaktadır (Ulutaş, 2012: 523-534). Bu defterlerden 285, 288, 289, 290, 291, 292, 293, 294, 295, 296, 297, 298, 299, 300, 303, 304, 305, 306, $308,309,312,313,314,316,317,318,319,324,325,385$ numaralı Şer'iyye Sicillerinde Mersin'e ait bilgiler bulunmaktadır (Bozkurt, 2001). Tanzimat dönemine kadar kadı sicilleri kadılık kurumunun görev ve sorumluluklarına paralel oldukça çeşitli konularda kayıtları içermektedir. Tanzimat ile birlikte bu defterlerde kadılık kurumunun görev ve yetki alanının daraltılması nedeni ile sadece mahkeme kayıtları ve tereke kayıtlarını bulmak mümkündür.

\section{Şûrâ-yı Devlet Belgeleri}

Şûrâ-y1 Devlet, 1868 tarihinde, Meclis-i Vâlâ'y1 Ahkâm-1 Adliye'nin lağv edilmesinden sonra Dîvân-1 Ahkâm-1 Adliye ile birlikte kurulmuş olan istişarî, icraî ve adlî bir kurumdur. 2 Mart 1868 tarihli kuruluş nizamnâmesinde Şûrâ-y1 Devlet, genel idari işlerin görüşüldüğü bir merkez olarak görev yapmaktadır. İlk Şûrâ-yı Devlet başkanı Midhat Paşa'dır (Başbakanlık Osmanlı Arşiv Rehberi, 2010: 224). Ayrıca Şûrâ-yı Devlet'in danışma, yasama, denetleme ve yargılama yetkileri de bulunmaktadır ( Yücesoy, 2017: 196-209). Şûrâ-yı Devlet'e ait defterlerin tasnifi devam etmekle birlikte, defterlerin bir kısmı belge kataloğu olarak kullanılmaktadır. Osmanlı Arşivi'ndeki Şûrâ-yı Devlet belgeleri içinde Mersin hakkında bilgi veren belgelerin kodu, açılımı ve kayıt sayıları aşağıda listelenmiştir.

Tablo 18. Mersin Tarihine İlişkin Şûrâ-yı Devlet Belgeleri

\begin{tabular}{|c|l|c|}
\hline KODU & \multicolumn{1}{|c|}{ AÇILIMI } & $\begin{array}{c}\text { KAYIT } \\
\text { SAYISI }\end{array}$ \\
\hline ŞD. & Şûrâ-yı Devlet Belgeleri & 330 \\
\hline
\end{tabular}


Kaynak: Cumhurbaşkanlığı Osmanlı Arşivi

Bu tasnifte Mersin ve çevresi ile ilgili ticaret, ziraat, dahiliye, rüsûmât, telgraf, orman, madenler, evkâf, maliye, nafia, serasker, defter-i hakâni, maaş tahsisleri gibi çok çeşitli konularda belgeler bulmak mümkündür.

\section{Ticâret, Nâfia, Orman, Maâdin ve Zirâat Nezâretleri Defterleri}

Nezaretler kurumsal olarak Osmanlı merkezi düzeninde yerini aldıktan sonra her bir nezaretin kendi içinde ve diğer kurumlarla olan yazışmaları içeren kayıtları mevcuttu. Osmanlı Arşivi'ndeki Ticâret, Nâfia, Orman, Maâdin ve Zirâat Nezâretlerine ait defterler içinde Mersin hakkında bilgi veren defterlerin kodu, açılımı ve kayıt sayıları aşağıda listelenmiş̧ir.

Tablo 19. Mersin Tarihine İlişkin Ticâret, Nâfia, Orman, Maâdin ve Zirâat Nezâretleri Defter Kayıtları

\begin{tabular}{|c|l|c|}
\hline KODU & \multicolumn{1}{|c|}{ AÇILIMI } & $\begin{array}{c}\text { KAYIT } \\
\text { SAYISI }\end{array}$ \\
\hline T..d... & $\begin{array}{l}\text { Ticâret, Nâfia, Orman, Maâdin ve Zirâat Nezâret } \\
\text { Defterleri }\end{array}$ & 3 \\
\hline
\end{tabular}

Kaynak: Cumhurbaşkanlığı Osmanlı Arşivi

$\mathrm{Bu}$ tasnifte Mersin ve çevresi ile ilgili demiryolu hattında meydana gelen kazalar, kazaların kayıt defterleri ve demiryolları ile ilgili bilgilerin olduğu belgeler yer almaktadır.

\section{Rumeli Müfettişliği Belgeleri (Taşradan Gelen Belgeler)}

Rumeli Müfettişliği 1902'de oluşturulmuştur. Bu tasnif Manastır, Selanik, Kosova, Yanya, Edirne ve İşkodra ile bu vilayetlere bağlı sancak, kaza, nahiye ve köylerine ait tahrirat kayıtlarını içermektedir. Rumeli Müfettişliği buralardan Bulgar, Rum, Sırp ve Arnavut eşkıya çeteleri ile fesat komitelerinin zararlı faaliyetleri; yabancı devletlerin zabitleri tarafindan yürütülen jandarma ve polis teşkilatı; konsolosların faaliyetleri; Patrikhâne faaliyetleri gibi önemli konularda gelen yazıların dışında, diğer idarî, malî, iktisadî, siyasî, ziraî, adlî ve ticarî konulardaki bütün resmî yazıları içermektedir (Başbakanlık Osmanlı Arşiv Rehberi, 2010: 411). Osmanlı Arşivi'ndeki Rumeli Müfettişliği Belgeleri içinde Mersin hakkında bilgi veren belgelerin kodu, açılımı ve kayıt sayıları aşağıda listelenmiştir. 
Tablo 20. Mersin Tarihine İlişkin Rumeli Müfettişliği Belgeleri (Taşradan Gelen Belgeler)

\begin{tabular}{|c|l|c|}
\hline \multicolumn{1}{|c|}{ KODU } & \multicolumn{1}{|c|}{ AÇILIMI } & $\begin{array}{c}\text { KAYIT } \\
\text { SAYISI }\end{array}$ \\
\hline TFR.I..AS.. & Rumeli Müfettişliği Sadâret Evrâk1 & 2 \\
\hline TFR.I..ŞKT. & Rumeli Müfettişliği Arzuhaller & 8 \\
\hline
\end{tabular}

Kaynak: Cumhurbaşkanlığı Osmanlı Arşivi

Bu tasnifte yer alan Mersin'le ilgili belgeler askerlik, memur atama ve terfileri, harcırah ödemeleri gibi konular hakkında veriler sunmaktadır.

\section{Yıldız Sarayı Arşivi Belgeleri}

Yıldız Saray Arşivi, II. Abdülhamid döneminde (1876-1909), Yıldız Sarayı'nda biriken defter, belge ve gazetelerden oluşan bir saray arşividir. $\mathrm{Bu}$ açıdan Topkapı Saray arşivinin bir devamı ve tamamlayıcısı niteliğindedir (Çetin, 1979: 564). Sultan II. Abdülhamid'in özel olarak ilgilendiği konular, Sadâret'ten saraya sunulmuş, ancak irâdeleri çıkmamış tezkireler; şahısların Yıldız Sarayı'na sundukları çeşitli arîza, rapor ve ihbarlar; Kâmil Paşa, Cevdet Paşa, Namık Kemal, Midhat Paşa gibi önemli kişilerin terekeleri(miras kayıtları), dış basında devletle ilgili çıkan yazılar, albüm ve resimler, kanun ve nizamnâme suretleri, Sultan II. Abdülhamid'e ait özel el defterleri ve cüzdanlar ile haritalar bulunmaktadır. Yıldız Evrâk1, uluslararası ilişkiler, Doğu Rumeli, Ermeni ve Mısır meseleleri, Girit Meselesi, sınır olayları gibi önemli devlet meselelerinden, Zabtiye jurnallerinde geçen adi vukuata kadar bu dönemin çeşitli özelliklerini yansıtan önemli bir fondur (Başbakanlık Osmanlı Arşiv Rehberi, 2010: 336). Osmanlı Arşivi'ndeki Yıldız Sarayı Arşivi Belgeleri içinde Mersin hakkında bilgi veren belgelerin kodu, açılımı ve kayıt sayıları aşağıda listelenmiştir.

Tablo 21. Mersin Tarihine İlişskin Yıldız Sarayı Arşivi Belgeleri

\begin{tabular}{|l|l|c|}
\hline \multicolumn{1}{|c|}{ KODU } & \multicolumn{1}{|c|}{ AÇILIMI } & $\begin{array}{c}\text { KAYIT } \\
\text { SAYISI }\end{array}$ \\
\hline Y..A...HUS. & Yıldız Sadâret Husûsî Marûzât Evrâk1 & 57 \\
\hline Y..A...RES. & Yıldız Sadâret Resmi Marûzât Evrâk1 & 24 \\
\hline Y..EE.. & Yıldız Esas Evrâk1 & 1 \\
\hline Y..EE..KP.. & Yıldız Dâhiliye Kamil Paşa Evrâk1 & 11 \\
\hline
\end{tabular}




\begin{tabular}{|c|c|c|}
\hline Y..MTV. & Yıldız Mütenevvi Marûzât Evrâk1 & 94 \\
\hline Y..PRK.A... & Y1ldız Perâkende Evrâkı Sadâret Marûzâtı & 6 \\
\hline Y..PRK.ASK. & Yıldız Perâkende Evrâkı Askeri Marûzât & 201 \\
\hline Y..PRK.AZJ. & Yıldız Perâkende Evrâkı Arzuhal Jurnal & 9 \\
\hline Y..PRK.AZN. & $\begin{array}{l}\text { Yıldız Perâkende Evrâkı Adliye ve Mezâhib } \\
\text { Nezâreti Marûzâtı }\end{array}$ & 6 \\
\hline Y..PRK.BŞK. & $\begin{array}{l}\text { Yıldız Perâkende Evrâkı Başkitabet Dairesi } \\
\text { Marûzâtı }\end{array}$ & 15 \\
\hline Y..PRK.DH.. & Yıldız Perâkende Evrâkı Dâhiliye Nezâreti Marûzâtı & 8 \\
\hline Y..PRK.EŞA. & $\begin{array}{l}\text { Yıldız Perâkende Evrâkı Elçilik Şehbenderlik ve } \\
\text { Ateşemiliterlik }\end{array}$ & 3 \\
\hline Y..PRK.HH.. & Y1ldız Perâkende Evrâk1 Hazîne-i Hâssa & 1 \\
\hline Y..PRK.HR.. & Yıldız Perâkende Evrâkı Hâriciye Nezâreti Marûzât1 & 2 \\
\hline Y..PRK.KOM. & Yıldız Perâkende Evrâkı Komisyanlar Marûzâtı & 52 \\
\hline Y..PRK.MBC. & Yıldız Perâkende Evrâkı Mabeyn Cetvelleri & 1 \\
\hline Y..PRK.MF.. & Yıldız Perâkende Maârif Nezâreti Marûzâtı & 3 \\
\hline Y..PRK.MK.. & $\begin{array}{l}\text { Yıldız Perâkende Evrâkı Müfettişlikler ve } \\
\text { Komiserlikler Tahriratı }\end{array}$ & 1 \\
\hline Y..PRK.ML.. & $\begin{array}{l}\text { Y1ldız Perâkende Evrâkı Evrâkı Mâliye Nezâreti } \\
\text { Marûzâtı }\end{array}$ & 3 \\
\hline Y..PRK.MŞ.. & Y1ldız Perâkende Evrâkı Meşîhât Dâiresi Marûzâtı & 1 \\
\hline Y..PRK.MYD. & $\begin{array}{l}\text { Y1ldız Perâkende Evrâkı Evrâk-1 Yaverân ve } \\
\text { Maiyyet-i Seniyye Erkan-1 Harbiye Dâiresi }\end{array}$ & 11 \\
\hline Y..PRK.OMZ. & $\begin{array}{l}\text { Y1ldız Perâkende Evrâkı Orman, Maadin ve Zirâât } \\
\text { Nezâreti Marûzâtı }\end{array}$ & 1 \\
\hline Y..PRK.PT.. & $\begin{array}{l}\text { Yıldız Perâkende Evrâkı Posta Telgraf Nezâreti } \\
\text { Marûzâtı }\end{array}$ & 13 \\
\hline
\end{tabular}




\begin{tabular}{|l|l|c|} 
Y..PRK.ŞD.. & Yıldız Perâkende Evrâkı Şûrâ-yı Devlet Marûzâtı & 1 \\
\hline Y..PRK.TKM. & $\begin{array}{l}\text { Yıldız Perâkende Evrâkı Tahrirat-1 Ecnebiye ve } \\
\text { Mabeyn Mütercimliği }\end{array}$ & 9 \\
\hline Y..PRK.TNF. & $\begin{array}{l}\text { Yıldız Perâkende Evrâkı Evrâkı Ticâret ve Nafia } \\
\text { Nezâreti Marûzâtı }\end{array}$ & 6 \\
\hline Y..PRK.UM.. & Yıldız Perâkende Evrâkı Umûmî & 81 \\
\hline Y..PRK.ZB.. & Yıldız Perâkende Evrâkı Zabtiye Nezâreti Marûzâtı & 21 \\
\hline
\end{tabular}

Kaynak: Cumhurbaşkanlığı Osmanlı Arşivi

$\mathrm{Bu}$ tasnifte Mersin'le ilgili bataklıkların temizletilip kurutulması, demiryolu inşası, çeşitli imar faaliyetleri, limana giriş çıkış yapan yabancı bandıralı gemiler, muhacirler, liman ve rıhtım inşası, karakol inşası, maden işletmeleri, askeriye, silah, mühimmat ve asker nakli, asayiş̧in temini, Mersin'e zahire ihracı vb. konularla ilgili belgeler bulmak mümkündür.

\section{Zabtiye Nezâreti}

Osmanlı merkezi düzeni içinde Zabtiye Nezâreti kamu düzeninin ve güvenliğin sağlanması konusunda önemli rol oynayan kurumlardan biridir. 1845 'te Zabtiye Müşirliği'nin kurulmasıyla Osmanlı'da ilk kez iç güvenlik birimleri idari ve hukuki olarak ordudan ayrılmıştır. 1881'den sonra ise bu kurumun görevini Polis müdürlükleri yürütmeye başlamıştır (Sönmez 2007: 2855-2864). Osmanlı Arşivi'ndeki Zabtiye Nezâreti tasnifi içinde Mersin hakkında bilgi veren belgelerin kodu, açılımı ve kayıt sayıları aşağıda listelenmiştir.

Tablo 22. Mersin Tarihine İlişkin Zabtiye Nezâreti Kayıtları

\begin{tabular}{|l|l|c|}
\hline KODU & \multicolumn{1}{|c|}{ AÇILIMI } & $\begin{array}{l}\text { KAYIT } \\
\text { SAYISI }\end{array}$ \\
\hline ZB & Zabtiye Nezâreti Evrâk1 & 127 \\
\hline
\end{tabular}

Kaynak: Cumhurbaşkanlığı Osmanlı Arşivi

$\mathrm{Bu}$ tasnifte Mersin ve çevresinin emniyet ve asayişi ile ilgili her türlü veri ve bilgiye ulaşmak mümkündür. Örneğin, işlenen suçları gösteren cetveller, deniz kol-sandalcıların maaşlarının ödenmesi, sahil güvenliği için istimbot tahsisi, jandarma ve polis komiserlerinin terfi ve atamaları, bulaşıcı hastalıklar için alınan önlemler, kaçak olarak Mersin'e gelenlerin geri gönderilmesi, Ermeni olayları, işgal süreci ve daha pek çok asayişle ilgili bilgi ve belge bulunmaktadır. 


\section{Mersin ile İlgili Diğer Arşiv Kayıtları}

Osmanlı Arşivi'ndeki Mevkûfât Kalemi ve Bağlı Birimlerine Ait Defterler, Timar Zeâmet (Rûznâmçe) Defterleri, Evkâf Defterleri, Fotoğraflar, Hazîne-i Hâssa İrâdeleri, Hibe, Satın, Devir-Tevfik Paşa Evrâkı, Kıbrıs Milli Arşivi-Fetva Eminliği Evrâkı, Topkapı Sarayı-Müze Arşivi Evrâkı, Taşra-Bosna Müfettişliği Evrâk1 içinde de Mersin hakkında bilgi veren belgeler bulunmaktadır. Bu belgelerin kodu, açılımı ve kayıt sayıları aşağıda listelenmiştir.

Tablo 23. Mersin Tarihine İlişkin Diğer Kayıtlar

\begin{tabular}{|l|l|c|}
\hline \multicolumn{1}{|c|}{ KODU } & \multicolumn{1}{c|}{ AÇILIMI } & $\begin{array}{c}\text { KAYIT } \\
\text { SAYISI }\end{array}$ \\
\hline D..MKF.d... & Mevkûfât Kalemi ve Bağlı Birimlerine Ait Defterler & 1 \\
\hline DFE.RZ.d... & Timar Zeâmet (Rûznâmçe) Defterleri & 5 \\
\hline EV.d... & Evkâf Defterleri & 33 \\
\hline FTG.f.. & Fotoğraflar & 4 \\
\hline HH.İ... & Hazîne-i Hâssa İrâdeler & 6 \\
\hline HSD.TVP & Hibe, devir-Tevfik Paşa Evrâk1 & 1 \\
\hline KB.MAA.FE.. & Kibrıs Milli Arşivi- Fetvâ Eminliği Evrâk1 & 3 \\
\hline TS.MA.e & Topkapı Sarayı - Müze Arşivi Evrâk1 & 7 \\
\hline TŞRBNM. & Taşra - Bosna Müfettişliği Evrâk1 & 1 \\
\hline
\end{tabular}

Kaynak: Cumhurbaşkanlığ 1 Osmanlı Arşivi

Bu tasniflerde Mersin ve çevresinden orduya yapılan zahire yardımı, yoklama defterleri, vakıflar, fotoğraflar, iskelelere atanan teftiş komisyonlarının ödemeleri, limanda çalışacak memurların atamaları, vakıf arazisine inşa edilen cami, askerlerin maaşlarını alamamaları vb. pek çok konuda belge bulmak mümkündür.

\section{Sâlnâmeler}

\section{Devlet Sâlnâmeleri}

Mersin kent tarihi ile ilgili faydalanılabilecek bir diğer kaynak türü de Devlet Sâlnâmeleridir. Osmanlı'da Devlet Sâlnâmeleri 1847'den itibaren çıkarılmaya başlanmış ve 1912 yılına kadar da düzenli bir şekilde yayınlanmıştır. Son cilt 1918 y1lına aittir. 1882 öncesi devlet salnameleri devletin yönetim ve ekonomik yönleri ile ilgili bilgiler içerir. Nüfus, bina sayısı, idari gelir ve giderler, öğrenci sayıs1, vs gibi istatistiki bilgiler mevcuttur. 1882 sonrasında ise yabanc1 konsoloslar da dâhil olmak üzere hükümet görevlilerinin listelerini de içerir. 
Vilâyetlerdeki kaza ve köylerin sayıları da istatistiki olarak verilmekteydi. Özellikle sınırların değişimi konusunda bilgiler mevcuttur. Bu açıdan kent tarihleri yazılırken idari yapılanma konusunda bu kaynaklarda önemli bilgiler bulmak mümkündür. Cumhuriyet sonrasında da devlet yıllıkları olarak devam ettiğini görmekteyiz. Nezâret ve vilayet salnameleri de aynı şekilde verimli bilgiler içermektedir (Palalı, 2010: 4-5). Devlet salnameleri, Cumhurbaşkanlı̆̆ 1 Osmanlı Arşivi'ndeki Devlet Sâlnâmeleri içinde Mersin hakkında bilgi veren salnameler aşağıda listelenmiştir.

Tablo 24. Mersin Tarihine İlişkin Devlet Sâlnâmeleri

\begin{tabular}{|l|}
\hline \\
\hline 1263 H. (1847 M.) Tarihli Devlet Sâlnâmesi \\
\hline 1300 H. (1883 M.) Tarihli Devlet Sâlnâmesi \\
\hline 1307 H. (1890 M.) Tarihli Devlet Sâlnâmesi \\
\hline $\begin{array}{l}\text { 1311 H. (1893/94 M.) Tarihli Devlet } \\
\text { Sâlnâmesi }\end{array}$ \\
\hline 1314 H. (1896 M.) Tarihli Devlet Sâlnâmesi \\
\hline 1315 H. (1897 M.) Tarihli Devlet Sâlnâmesi \\
\hline 1316 H. (1898 M.) Tarihli Devlet Sâlnâmesi \\
\hline 1317 H. (1899 M.) Tarihli Devlet Sâlnâmesi \\
\hline 1318 H. (1900 M.) Tarihli Devlet Sâlnâmesi \\
\hline 1321 H. (1903 M.) Tarihli Devlet Sâlnâmesi \\
\hline 1322 H. (1904 M.) Tarihli Devlet Sâlnâmesi \\
\hline 1323 H. (1905 M.) Tarihli Devlet Sâlnâmesi \\
\hline 1324 H. (1906 M.) Tarihli Devlet Sâlnâmesi \\
\hline 1325 H. (1907 M.) Tarihli Devlet Sâlnâmesi \\
\hline 1326 H. (1908 M.) Tarihli Devlet Sâlnâmesi \\
\hline 1327 R. (1911 M.) Tarihli Devlet Sâlnâmesi \\
\hline 1328 R. (1912 M.) Tarihli Devlet Sâlnâmesi \\
\hline $\begin{array}{l}\text { 1333-34 R. (1918 M.) Tarihli Devlet } \\
\text { Sâlnâmesi }\end{array}$ \\
\hline
\end{tabular}

Kaynak: Cumhurbaşkanlığı Osmanlı Arşivi

\section{Vilâyet Sâlnâmeleri}

1864 'te ilk Vilâyet Nizamnamesinin çıkarılmasından sonra vilayetler idari anlamda yeniden bir düzenlemeye tabi tutulmuş ve vilayet matbaalarında salnameler basılmaya başlanmıştır (Akbayar, 1985: 1247-1248). Vilâyet 
Sâlnâmeleri XIX ve XX. yüzyıl Osmanlı Taşrasına ilişkin oldukça zengin veriler içerir. Bu kaynaklarda vilâyetlerin idari taksimatı, devlet dairelerinin ve buralarda görevli yönetici ve memurların isimleri, nüfus kayıtları, köy isimleri, maaş cetvelleri, zirai ve sınai üretim, gelir gider istatistikleri, tarihi bilgiler gibi bilgiler bulmak mümkündür (Palal1, 2010: 8).

Vilâyet Sâlnâmelerinde merkez dışındaki kentlerin idari, sosyal, etnik, kültürel ve ekonomik yapısına dair bilgiler yer almaktadır.

Mersin kent tarihine yönelik bilgilere Adana ve Halep Vilâyet Sâlnâmelerinde ulaşmak mümkündür. Adana Vilâyet Sâlnâmesi'nin ilki 1870 y1lında yayınlanmıştır. Mersin'i kapsayan toplam 12 adet Adana Vilâyet Sâlnâmesi bulunmaktadır. Halep Vilâyet Sâlnâmelerinde de bir süre buraya bağlı olmasından dolayı Mersin'e yönelik bilgiler bulunmaktadır. Mersin'e dair bilgileri içeren Adana ve Halep Vilâyet Sâlnâmeleri aşağıda listelenmiştir.

Tablo 25. Vilâyet Sâlnâmeleri

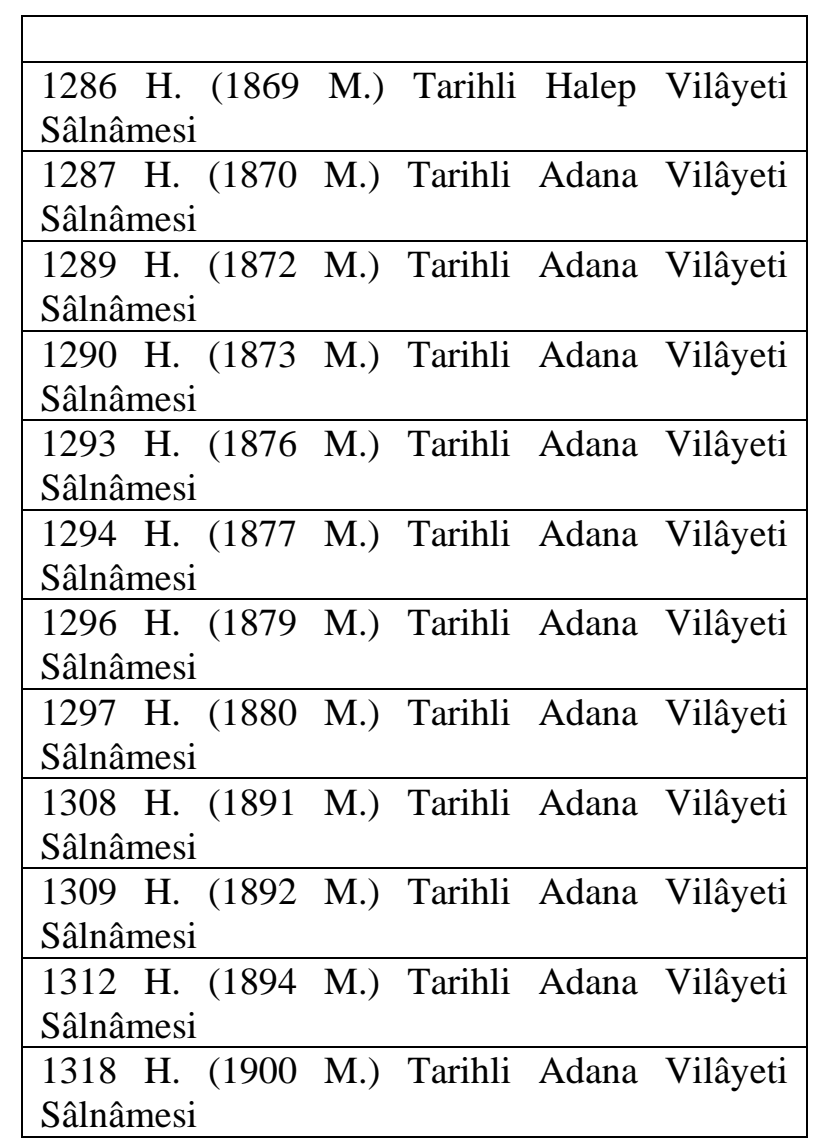




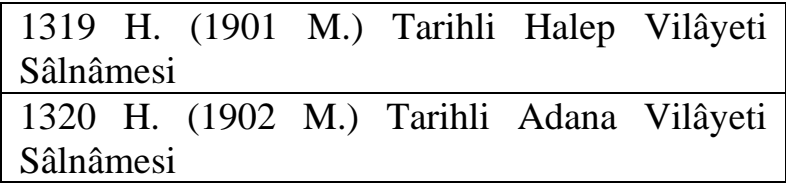

Kaynak: Cumhurbaşkanlığı Osmanlı Arşivi

\section{Maarif ve İlmiyye Sâlnâmeleri}

Osmanlı Maârif Nezâreti tarafından çıkarılan yıllıklardır. Bu yıllıklarda yapılan eğitim ve öğretim faaliyetleri hakkında bilgiler sunulmakla birlikte vilayetlerde ve sancaklarda bulunan okullar ve sayıları, bu okullarda eğitim veren öğretmen ve öğrencilerin sayıları ve isimleri hakkında bilgiler verilmektedir. Mersin Sancağı'ndaki okullarla ilgili bilgiler 1319 H. (1901 M.) Tarihli Maârif Sâlnâmesi, 1321 H. (1903 M.) Tarihli Maârif Sâlnâmesi ve 1334 H. (1915-1916 M.) Tarihli İlmiyye Sâlnâmesi'nde yer almaktadır.

\section{Sonuç}

$\mathrm{Bu}$ çalışmada, Mersin tarihine ilişkin Osmanlı Arşivinde ne gibi belgeler bulunduğu ve bunların miktarı ve içeriği hakkında bilgiler verilmiştir. Böylece Mersin Tarihine 1 şı tutacak çok sayıda arşiv kaydı araştırıcının bilgisine sunulmuştur. Araştırmamızın amacı, Osmanlı Dönemi Mersin'ine ilişkin Osmanlı Arşivinde ne türden ve miktarda kaynağın bulunduğu ve bu birbirinden farklı kaynakların Mersin'in hangi alanıyla ilgili bilgiler verdiğini ortaya koymaktır. Kaynakların her birinin açıklaması yapılarak buralardan ne tür veriler elde edilebileceği hakkında bilgiler verilmesi, araştırıcıya kaynak hakkında da yol göstermektedir. Yapılan araştırmalar sonucunda arşivde farklı fonlarda perakende ve defter şeklinde bulunan bu tasnifler içerisinde Osmanlı Dönemi Mersin Tarihi üzerine 6925 adet kayıt bulunduğu tespit edilmiştir. Tespit edilen bu kayitlar arşivin içinde elektronik tarama sonucunda elde edilen belgeleri içermektedir. Arşivde koruma altında bulunan belgelerin uzmanlar tarafından tasnif çalışmalarının devam ettiği düşünüldüğünde çok daha fazla kaydın mevcut olduğu gerçeği göz önünde bulundurulmaktadır. Tespit edilen bu kayıtların dışında tarama esnasında kaydı çıkmayan fakat mevcut farklı konulardaki belgelerin içeriklerinde de Mersin ile ilgili bilgiler olabileceği mümkündür.

Bu çalışma ile aynı zamanda herhangi bir konuda Osmanlı Dönemi kurumları arasındaki iletişimi de ortaya koymak mümkün olmuştur. Hangi kurumun hangi konularda etkin olduğu böylece ortaya çıkmaktadır. Özellikle Tanzimat döneminde Osmanlı merkezi düzeninde gerçekleşen bürokratik reform sonucu resmi devlet kurumlarının kendi aralarında uzmanlaşmaya doğru gittiği de bu minvalde açıkça görülmektedir. Özellikle 17. yüzyılın sonlarından itibaren 
Sadaretin önem kazanması ile bu kurumla olan yazışmaların da paralel ölçüde arttığ dikkat çekmektedir.

Çalışmamız boyunca dikkat çeken bir diğer konu Mersin'le ilgili tespit edilen belgeler arasında en fazla yoğunluk Dâhiliye Nezareti'ne ait tasniftedir. Bunun önemli bir sebebi özellikle 19. yüzyıl itibari ile hem Dâhiliye Nezareti’nin Osmanlı merkezi yönetiminde en önemli kurum olması hem de bu süreçte Mersin'in idari bir birim olarak henüz yeni yeni gelişmeye başlamasıdır. $\mathrm{Bu}$ sebeple de belgelerin büyük bir kısmı çoğunlukla 19. ve 20. yüzyıla aittir. Bunun yanı sıra diğer önemli bir tespit özellikle 1850'lerden sonra Mersin'in bir liman kent olarak giderek büyümesi ve kozmopolit bir yapıya sahip olması sonucu dış ilişkilerinde giderek artan bir hareketliliğe sebep olmasıdır. Bu bağlamda Dâhiliye Nezareti'nden sonra nitel ve nicel olarak yoğun olan diğer bir tasnifin Hariciye Nezareti olduğu görülmektedir. Bu dönem belgelerine bakıldığında çoğunlukla Mersin'in sosyo-kültürel ve idari yapısındaki büyümeyle ilgili olduğu da dikkat çekmektedir.

Bu çalışma Osmanlı Dönemi kent tarihi çalışmak isteyen araştırıcıların Mersin örneğinden hareketle Osmanlı Arşivi'nde hangi kaynaklara bakıp ne tür veriler elde edebileceği konusunda fikir sahibi olmalarını sağlayabilir niteliktedir. Tespitlerimize göre Osmanlı dönemi Mersin Kent Tarihine ilişkin Osmanlı Arşivinde bulunan belgelerde kentin sosyo-ekonomik, kültürel, kurumsal üst yapılanması içinde tarım, ticaret, sanayi gibi üretim sektörleri, idari kurumları çerçevesinde taşra teşkilatlanması, sosyal yaşam çerçevesinde toplumsal sınıfların ilişkileri, kültürel aktiviteleri, gündelik hayatı vb. pek çok alanıyla ilgili veriler elde etmek mümkündür. Bu açıdan çalışma önemli bir yol gösterici niteliği de taşımaktadır. Mersin Tarihine ilişkin böyle bir çalışmanın olmayışı nedeniyle alana katkı sunacağı da düşünülmektedir.

\section{KAYNAKÇA}

Akbayar, Nuri (1985), “Osmanlı Sâlnâmeleri”, Tanzimat’tan Cumhuriyet'e Türkiye Ansiklopedisi, Cilt 5, İletişim Yayınları, İstanbul, ss. 1247-1248.

Akgündüz, Ahmet (1998), Şer’iyye Sicilleri, Mahiyeti, Toplu Kataloğu ve Seçme Hükümler, Cilt I, Türk Dünyası Araştırmaları Vakfı Yayınları, İstanbul.

Akpınar, Mahmut (2014), “Osmanlı İmparatorluğu'nda Hâriciye Nezâreti'nin kuruluşu ve Dış Politikanın Kurumsallaşması”, Tarih İncelemeleri Dergisi, Cilt XXIX/1, ss. 59-85.

Akyıldız, Ali (2003), "Meclis-i Vâlâ-yı Ahkâm-ı Adliye", Türkiye Diyanet Vakfi İslam Ansiklopedisi, Cilt 28, Ankara, ss. 250-251. 
Başbakanlık Osmanlı Arşiv Rehberi, (2010), Osmanlı Arşiv Daire Başkanlığı Yayınları, İstanbul.

Bozkurt, İbrahim (2001), Sâlnâmelerde Mersin, Mersin Üniversitesi Sosyal Bilimler Enstitüsü Tarih Anabilim Dalı, Yayınlanmamış Yüksek Lisans Tezi, Mersin.

Bozkurt, İbrahim (2018), Tanzimat'tan Cumhuriyete Mersin Tarihi, Mersin Büyükşehir Belediyesi Kültür Yayınları, Mersin.

Braudel, Fernand (2001), Uygarlıkların Grameri, Çeviren: Mehmet Ali Kılıçbay, İmge Yayınevi, İstanbul.

Çelik, Şenol (2000), “İçel”, Türkiye Diyanet Vakfı İslam Ansiklopedisi, Cilt 21, İstanbul, ss. 50-55.

Çetin, Atilla (1979), "Yıldız Arşivi’ne Dair”, Tarih Dergisi/Turkish Journal of History, Say1 XXXII, ss. 563-586.

Durukan, Murat (2015), Mersin'den Tarsus'a Kilikya Kıyılarındaki Kayıp Kentler, Arkeoloji ve Sanat Yayınları, İstanbul.

Findley, Carter Vaughn (1997), "Hâriciye Nezâreti”, Türkiye Diyanet Vakfi İslam Ansiklopedisi, Cilt 16, Türkiye Diyanet Vakfi Yayınları, İstanbul, ss. $178-180$.

İpşirli, Mehmet (1991), “Bab-ı Ali”, Türkiye Diyanet Vakfi İslam Ansiklopedisi, Cilt 4, Türkiye Diyanet Vakfı Yayınları, İstanbul, ss. 386-389.

Kütükoğlu, Mübahat (1997), “Hatt-ı Hümâyûn”, Türkiye Diyanet Vakfı İslam Ansiklopedisi, Cilt 16, Türkiye Diyanet Vakfi Yayınları, İstanbul, ss. 485487.

Kütükoğlu, Mübahat (2000), “İrâde-i Seniyye”, Türkiye Diyanet Vakfı İslam Ansiklopedisi, Cilt 22, Türkiye Diyanet Vakfı Yayınları, İstanbul, ss. 391392.

Kütükoğlu, Mübahat (2006), “Mühimme Defteri”, Türkiye Diyanet Vakfı İslam Ansiklopedisi, Cilt 31, Türkiye Diyanet Vakfi Yayınları, İstanbul, ss. 520523.

Oğuz, İbrahim (2005), Mersin Kentinin Kuruluş Öyküsü, Mersin Ticaret ve Sanayi Odası Yayınları. 
Özel, Oktay ve Çetinsaya, Gökhan (2002). “Türkiye'de Osmanlı Tarihçiliğinin Son Çeyrek Yüzyılı: Bir Bilanço Denemesi”, Toplum ve Bilim Dergisi, Say1 91, ss. 8-38.

Palalı, İlhan (2010), "Osmanlı Sâlnâmeleri ve Tarih Araştırmalarındaki Kaynak Olarak Önemi”. Harran Üniversitesi İlahiyat Fakültesi Dergisi, Sayı 23, ss. 1-14.

Sayar, Ahmet Güner (2005), “Muallim Cevdet”, Türkiye Diyanet Vakfi İslam Ansiklopedisi, Cilt 30, Türkiye Diyanet Vakfı Yayınları, İstanbul, ss. 313314.

Sertoğlu, Mithat (1955), Muhteva Bakımından Başvekâlet Arşivi, Türk Tarih Kurumu Yayınevi, Ankara.

Sönmez, Ali (2007), “Osmanlı Devleti’nde İç Güvenliğin Dönüşümü: Zaptiye Teşkilatı'ndan Jandarma'ya”. Uluslararası Asya ve Kuzey Afrika Çalışmaları Kongresi Bildirileri, Cilt VI. ss. 2855-2864.

Tekeli, İlhan (1998), “Kent Tarihi Yazımı Üzerine Düşünceler”, Tarih Yazımı Üzerine Düşünmek, Editör: İlhan Tekeli, Dost Kitabevi, Ankara, ss. 148165.

Uğur, Yunus, (2010) "Şer'iyye Sicilleri”, Türkiye Diyanet Vakfi İslam Ansiklopedisi, Cilt 39, Türkiye Diyanet Vakfı Yayınları, İstanbul, ss. 8-11.

Ulutaş, Songül (2012), "Osmanlı Kaynakları ve Tarsus", The Journal of Academic Social Science Studies, Volume 5 Issue 6, December, ss. 523534.

Ünlü, Tülin Selvi (2007), 19.Yüzyılda Mersin'in Kentsel Gelişimi, Mersin Üniversitesi Sosyal Bilimler Enstitüsü Tarih Anabilim Dalı, Yayınlanmamış Yüksek Lisans Tezi, Mersin.

Yazıcı, Serkan, "Şark Ticâret Yıllıklarına Göre Üç Devirde İzmit Şehrinde Ticâret”, Uluslararası Gazi Süleyman Paşa ve Kocaeli Tarihi Sempozyumu-III, Kocaeli, ss. 1783-1816.

Yurtseven, Yılmaz (2002), "Klasik Dönem Osmanlı Mâliye Teşkilatı ve Sistemi”, Selçuk Üniversitesi Hukuk Fakültesi Dergisi, Cilt 10, ss. 109121.

Yücesoy, Ayşe Aslı (2017), “Şûrây-ı Devlet (1868-1876)”, İnönü Üniversitesi Hukuk Fakültesi Dergisi, Cilt 8, Sayı 2, ss. 187-216. 